NBER WORKING PAPER SERIES

\title{
CHILD CARE IN POOR COMMUNITIES: \\ EARLY LEARNING EFFECTS OF TYPE, QUALITY, AND STABILITY
}

\author{
Susanna Loeb \\ Bruce Fuller \\ Sharon Lynn Kagan \\ Bidemi Carrol \\ Judith Carroll \\ Jan McCarthy \\ Working Paper 9954 \\ http://www.nber.org/papers/w9954 \\ NATIONAL BUREAU OF ECONOMIC RESEARCH \\ 1050 Massachusetts Avenue \\ Cambridge, MA 02138 \\ September 2003
}

The views expressed herein are those of the authors and not necessarily those of the National Bureau of Economic Research.

(C)2003 by Susanna Loeb, Bruce Fuller, Sharon Lynn, Kagan, Bidemi Carrol, Judith Carroll, and Jan McCarthy. All rights reserved. Short sections of text, not to exceed two paragraphs, may be quoted without explicit permission provided that full credit, including (C) notice, is given to the source. 
Child Care in Poor Communities: Early Learning Affects of Type, Quality, and Stability Susanna Loeb, Bruce Fuller, Sharon Lynn, Kagan, Bidemi Carrol, Judith Carroll, and Jan McCarthy

NBER Working Paper No. 9954

September 2003

JEL No. I0, I2, I3

\begin{abstract}
$\underline{\text { ABSTRACT }}$
Young children in poor communities are spending more hours in non-parental care due to policy reforms and expansion of early childhood programs. Studies show positive effects of high-quality center-based care on children's cognitive growth. Yet we know little about the effects of center care typically available in poor communities or the effects of home-based care. Using a sample of children age 12 to 42 months when their mothers entered welfare-to-work programs, this paper finds positive cognitive effects for children in center care. Children also display stronger cognitive growth when caregivers are more sensitive and responsive, and stronger social development when providers have education beyond high school. Children in family child care homes show more behavioral problems but no cognitive differences.
\end{abstract}

Susanna Loeb

Stanford University

224 CERAS, 520 Galvez Mall

Stanford University

Stanford, CA 94305

and NBER

sloeb@stanford.edu

Bruce Fuller

University of California, Berkeley

Sharon Lynn Kagan

Teachers College, Columbia University
Bidemi Carrol

Stanford University

Judith Carroll

Yale University

Jan McCarthy

University of South Florida 


\section{INTRODUCTION $^{1}$}

In recent years, policy shifts that encourage mothers to leave home and enter paid jobs have influenced the number of parents selecting nonparental child care and the types of settings children enter. In addition, growth in federal child care vouchers for a wider range of lowincome and working-class families has spurred demand for both center and home-based care, including licensed child care homes and subsidized individual caregivers (Blau, 2001; Collins, Layzer, Kreader, Werner, \& Glantz, 2000). High-quality early childhood programs, typically situated within centers or preschools, have demonstrated significant effects on early language and cognitive development for children from low-income families (for review, Barnett, 1995; Burchinal, 1999; Currie, 2001). Yet, effects for similar children in "naturally" varying centers across poor communities are more mixed, likely due to wide variation in program quality (Phillips, Voran, Kisker, Howes, \& Whitebook, 1994). Center care for infants that manifests low quality may even depress early cognitive growth, relative to parental care (Vandell \& Corasaniti, 1990; NICHD Early Child Care Research Network, 1997). The limited observational evidence available reveals highly variable quality of care in poor communities (Coley, Li-Grining, \& Chase-Lansdale, in press; Phillips et al., 1994). We know little about the quality of care selected under the new policy regime by mothers moving from welfare to work. We also know little about the effects of these settings on their young children's development.

This paper reports on the observed quality of center and home-based child care settings selected by single mothers soon after they entered welfare reform programs in 1998 . We estimate how young children's exposure to center versus home-based care, care quality, and care stability affect early cognitive and social development, net baseline levels of cognitive and social proficiencies, the mother's own cognitive ability and education level, and several other background factors. We also report a selection analysis to determine whether self-selection of care may be biasing our estimates.

\section{Developmental Effects of Child Care Type and Quality}

Carefully crafted preschool programs repeatedly have shown significant effects on young children's cognitive growth and, occasionally, on their social development. Such effects from small demonstration programs were first found with the Perry Preschool Project (Schweinhart, Barnes, Weikart, Barnett, \& Epstein, 1993) and elaborated in similarly controlled interventions, 
such as the Abecedarian full-day preschool program (Campbell \& Ramey, 1994), the Infant Health and Development Project (McCarton, Brooks-Gunn, Wallace, \& Bauer, 1997), and the Chicago Child-Parent Centers (Reynolds \& Temple, 1998). Random-assignment designs have been used more recently, revealing discrete developmental effects within a portion of Early Head Start sites (Love et al., 2002) and for welfare-reform experiments when they attend to parents' child care needs and increase the selection of center-based programs. The New Hope experiment in Milwaukee is one example (Huston et al., 2001; Zaslow et al., 2002).

Generalizing effects from these demonstration programs to broadly available child care programs is difficult. Studies assessing the impact of centers - within both middle-class and low-income neighborhoods - tends to show less consistent effects on young children's cognitive growth. These estimates also tend to diminish when more extensive selection controls are included in estimation models (Burchinal, 1999; Fuller, Holloway, \& Liang, 1996). Some investigators have found no significant effects from children's participation in center programs when they have drawn samples which presumably capture wider variability in center quality than was observed in the earlier demonstration projects (Clarke-Stewart, Gruber, \& Fitzgerald, 1994; Kontos, 1991). The magnitude with which center care affects cognitive growth has been an issue with Head Start, given that positive effects have been modest and at times short lived, as children enter elementary schools of uneven quality (Lee \& Loeb, 1995; NICHD Early Child Care Research Network, 1999).

In contrast to studies assessing child care type, studies looking at the influence of center quality on children's outcomes tend to find effects. The Cost, Quality, and Outcomes Study, tracking children who attended centers in widely varying communities in four states, finds that quality indicators predict cognitive and social developmental gains into kindergarten and, for some outcomes, into second grade (Peisner-Feinberg et al., 2001). Effect sizes, though modest in most cases, are stronger for children from low-income families, even though the average quality of centers the children attended was moderate to low (Peisner-Feinberg \& Burchinal, 1997). In one welfare reform experiment, when mothers facing stiff work requirements were able to find high-quality center care, their young children displayed higher levels of school readiness, compared to those in the control group whose mothers faced little employment pressure (Zaslow, McGroder, Moore, \& Le Menestrel, 1999; Zaslow, Oldham, Moore, \& Magenheim, 1998). The NICHD (1997) study of early child care also found positive cognitive-developmental 
effects and mixed social-developmental effects from quality levels and time spent in centerbased programs, even for toddlers. Yet this study tracked only a small number of children from poor families.

Maternal Employment, Child Care Selection, and Local Supply Conditions Marked shifts in family policy over the past decade have influenced demand for child care and the mix of organizations and individuals that provide care in poor communities. The process of child care selection, the availability of home-based providers, and care quality may all be changing as welfare reforms become institutionalized, spurring greater demand for child care and sizeable infusions of new funding (Fuller, Kagan, Caspary, \& Gauthier, 2002). One federal study reported that over one million additional families now receive public child care support each year, compared to before the 1996 reforms (Collins et al., 2000). Initial observational studies of centers selected by welfare and working-poor families reveal widely varying levels of quality (Coley, Li-Grining, \& Chase-Lansdale, in press; Fuller, Kagan, \& Loeb, 2002). As the mix of providers evolves in poor communities and additional families express demand for nonparental care, it becomes more difficult to generalize from the early evaluations of the preschool demonstration programs. Findings of positive effects from high-quality centers alone cannot answer the question: On average, do children in poor communities benefit developmentally when placed in centers as their mothers are encouraged to move from home into paid jobs?

We know even less about the quality or impact of home-based care - licensed family child care homes (FCCHs) and kith or kin providers. One rare observational study found mixed but generally low quality in home-based settings (Kontos, 1991). The NICHD study found that the quality of center versus home-based care may depend upon the child's age (Clarke-Stewart, 1999). In-home care provided by grandparents and fathers was determined to be of higher quality, compared to center-based programs, for toddlers at 15 and 24 months of age. But for preschoolers, center-based programs surpassed home-based settings on a variety of indicators. But, again, the NICHD sample includes only a modest share of low income families.

In order to accurately estimate the impact of child care on children's development, we must consider the process by which mothers select child care settings for their children. Under strong and immediate pressure to work outside the home, low-income mothers may be 
constrained in their choices, depending on the stock of care options available locally. In this case, the mother's own attributes may have little effect on child care choice. If children are allocated into center slots by caseworkers, traditional conceptions of demand factors operating solely at the individual level are not sufficient. In addition, state regulatory policies may affect the distribution of center quality. Two studies have shown that the quality of centers situated in low-income neighborhoods, at least along structural measures (e.g., child-staff ratios), can be moderate to high, compared to unregulated or non-subsidized centers (Phillips, Voran, Kisker, Howes, \& Whitebook, 1994; Fuller \& Holloway, in press). Alternatively, children exposed to risk factors at home may display a higher likelihood of being placed in home-based settings or in poorer quality centers (Belsky, Spritz, \& Crnic, 1996; Tresch Owen \& Cox, 1988), leading to selection bias when estimating discrete effects of nonparental child care. We focus considerable analytic attention on detecting potential bias arising from selection

\section{Empirical Questions}

Earlier studies and evolving family policies prompt four empirical questions. First, what is the quality of child care available to women in the welfare system? Second, how does the type and quality of child care attended influence childrens' cognitive development? Early evidence suggests that high-quality center programs more effectively contribute to children's cognitive and language development than home-based providers; but these data are sparse, stem from controlled demonstrations, and were collected prior to implementation of the 1996 welfare reforms. Third, how does the type and quality of child care influence young children's social development? Earlier evidence on social-developmental effects of child care settings is mixed. We know little about possible effects in poor communities. Finally, do differences in developmental effects hold up to extensive controls for family differences in children's baseline proficiencies, mothers' own cognitive skills, home practices, and other family attributes? The magnitude of observed center effects has been moderate in naturalistic settings and typically diminishes when more thorough selection controls are included in estimation models.

\section{METHOD}

Our analysis stems from a five-year study that is following low-income mothers and young children who, in 1998, entered state welfare-to-work programs, under the new federal 
Temporary Assistance for Needy Families (TANF) program. Our overall goal is to understand how home and child care environments change for children as their mothers face new pressures and incentives to work outside the home.

\section{Procedure and Participants}

The present paper reports on data collected from maternal interviews, child assessments, and observations of center care and home-based care settings for 451 families residing in San Francisco or San Jose, California, or Tampa, Florida. We selected research sites based on demographic diversity, variation in local policy conditions, variation in the stock of center programs among the census tracts in which low-income families resided, and cooperation of county welfare officials. We conducted maternal interviews and child assessments primarily in 1998 (baseline, wave 1), when the mean child was 21/2 years of age, and in 2000 (wave 2), when the mean child was approximately four years old.

We invited mothers into the study during their first visit to the local welfare office after TANF eligibility was determined by each county. All mothers were TANF-eligible at baseline (wave 1), were a single head of household, and had at least one resident child 12-42 months of age. Eighty-nine percent of the women meeting these sampling requirements agreed to join the study. We conducted maternal interviews at both waves 1 and 2, covering several child care topics as well as questions about the development of their child. At wave 1, we assessed children's baseline cognitive, language, and social-developmental proficiencies and conducted child care observations. At wave 2, we conducted home visits, allowing a wider battery of childassessment measures.

The 451 families who participated in wave 2 comprise 77 percent of the original baseline (wave 1) sample. A sample-attrition analysis reveals that families who left the wave 1 sample did not differ significantly from the retained sample in terms of mother's age and school attainment, employment status, or children's wave 1 cognitive and language development scores. Children who exited the sample were about 3 months older than those retained; this should not affect our estimation models, since we control for age in the analyses. Due to a low response rate in wave 2 of Vietnamese-American families in San Jose, we omitted this subgroup from the present analysis. 
Table 1 reports characteristics of the 451 California and Florida families who participated in both wave 1 and wave 2 data collection. The families are evenly distributed across the three research sites as follows: 31 percent San Jose $(\underline{n}=139), 35$ percent San Francisco $(\underline{n}=159)$, and 34 percent Tampa $(\underline{n}=153)$. Forty-one percent of mothers are African American, 32 percent are Latina, and 24 percent are white. Eighty-three percent of mothers were employed at some point in the year before the wave 2 interview. Their average monthly income (from earnings plus cash benefits) was $\$ 1,008$, despite their success in finding jobs.

[Table 1 about here]

During the baseline (wave 1) interviews, 68 percent of the mothers used some type of nonparental child care at least 10 hours a week. As maternal employment rose, so did child care use. By wave 2, 83 percent of mothers were using nonparental care. The share of women using center care increased markedly, rising from 29 percent to 40 percent between waves 1 and 2 . In part this increase is due to children's aging over time: national surveys show that as children reach age three or four, enrollment in center programs increases (Smith, 2000). Over the two waves of data collection, many mothers changed child care at least once. Twenty-one percent of children were in center care at both waves; 19 percent moved to a center between waves 1 and 2; four percent were in a family child care home $(\mathrm{FCCH})$ at both waves; 16 percent were with an individual nonparental provider; 31 percent were in a mixed arrangement; and nine percent reported not using care at either wave 1 or wave 2.

\section{Measures}

Maternal and home characteristics. The interviews with mothers, conducted at wave 1 (baseline) and wave 2, covered a variety of individual attributes and features of the home environment. For the present analyses, we draw on several of these variables as predictors of developmental outcomes. We control for these factors in our analyses to distinguish the effect of different types of child care from the selection of families into child care settings (Burchinal, 1999; Peisner-Feinberg et al., 2001). Demographic controls include mother's age, ethnicity, monthly income, and school attainment level. We asked a series of questions regarding the mother's work experiences over the prior 12 months and involvement in the welfare system. We sort women into four groups, based on whether they were currently working and whether they were still drawing cash aid under the TANF program, and include controls for these groups in 
our analyses. In addition, we employed questions from the HOME Inventory on parenting practices, including the mother's reported reading behaviors and engagement with the focus child in activities related to positive development (e.g., reading with the child; Bradley, 1993). Such practices might influence both child development and child care selection, and thus their omission could bias estimates of child care effects (Fuller, Holloway, \& Liang, 1996).

In addition to controlling for the factors discussed above, we adjust for mothers' cognitive proficiency and mental health. During our wave 2 home visits, we administered the adult version of the Peabody Picture Vocabulary Test in English or Spanish, assessing the mother's cognitive and language proficiency (PPVT; Dunn \& Dunn, 1997). To assess mental health, we used the Center for Epidemiologic Studies Depression Inventory (CES-D; McDowell $\&$ Newell, 1996), consisting of self-reported items such as "you felt lonely"; "you were happy"; and "you could not shake off blues, even with help from family and friends." Just over two in every five mothers in our sample displayed depressive symptoms at waves 1 and $2 .^{2}$

Child care exposure, type, and stability. Children's exposure to differing types of child care is indicated by a series of dummy variables measuring: whether a child attended a center at both wave 1 and wave 2, attended a licensed FCCH at both waves, had no nonparental care arrangement in both waves, moved to a center by wave 2, or experienced another mix of child care types over the two waves. The base group includes children who were cared for by individual kith or kin members in waves 1 and 2. We asked mothers how many child care providers they currently were utilizing, and for how many months the focal child had been attending the current provider setting. These two measures assess the stability of the primary child care arrangement, enabling us to differentiate the effects of quality from the effects of stability.

Observed child care quality. During wave 1 data collection, we accessed child care settings to conduct half-day observations of quality features. We observed 158 centers (out of 196) and 136 home-based settings (out of 228), 69 percent of the settings attended by children in care for at least 10 hours per week. We measured quality using standard measures, such as the Early Childhood Environment Rating Scale (ECERS). The ECERS gauges a variety of structural and physical aspects of centers, such as the quality of facilities, availability of developmentally appropriate learning and play materials, the arrangement of child-centered activities, and the nature of child-caregiver interaction (Harms, Clifford, \& Cryer, 1997). We used the counter-part 
instrument for family child care homes, the Family Day Care Rating Scale (FDCRS), in all home-based settings, including kith or kin providers. Early in our project, we conducted a validation study to see how these instruments performed in center and home settings in lowincome communities (authors' citation). We decided to use the ECERS, rather than the Infant/Toddler Environment Rating Scale (ITERS) for our wave 1 child care observations, assuming that most children would be at the upper end of our age distribution. This proved to be true: two-thirds of the 55 children enrolled in centers at wave 1 were 24 months or older. Since our sample was already split between children in center care and those in home-based care, we did not want to introduce another quality measure for this small subgroup of young toddlers, for whom the ITERS may have been preferable.

We also administered the Arnett Scale of Caregiver Behavior (Arnett, 1989). This scale focuses on the character of social interaction between child and caregiver, including the caregiver's attentiveness and responsiveness, capacity to explain misbehavior and reason, and warmth and generalized affect. Items coded by the field researcher include, "(caregiver) speaks warmly to the children" and "pays positive attention to the children as individuals." It also measures the extent to which caregivers engage children in problem solving activities, rather than being directive.

Field staff were trained centrally on the observations measures, and all were required to reach a 90 percent level of inter-rater agreement on individual scales within the ECERS, FDCRS, and the Arnett measures. Finally, we obtained structural measures of quality (Phillips, et al., 1994) through an interview with the child care provider. These measures include childstaff ratios, maximum group size, number of child groups at the setting, and the provider's education level and past participation in child development training and inservice workshops.

Table 2 reports mean scores on the quality measures for centers and home-based settings, split by research site. Caregivers in centers have higher educational attainment than those in home-based settings; though, as expected, the ratio of children to adults is higher in centers. In our sample, both child care types exhibited similar scores on the Arnett scale. Note that the ECERS and FDCRS are not directly comparable, especially given limited experience using the FDCRS in kith and kin settings. We, however, can compare the ECERS and FDCRS across sites. The California counties, especially San Jose, exhibit higher ECERS scores and appear to be of higher quality across all the measures. In an earlier paper, we separated licensed FCCHs 
from individual providers, but detected few differences between these two groups (authors' citation). The multivariate analysis below does distinguish between FCCHs and kith or kin providers.

[Table 2 about here]

Children's cognitive and language proficiencies. During both waves of data collection, we assessed children with the two subscales of the MacArthur Communicative Development Inventory (CDI, Fenson, 1994). These measures rely on mother's report of her child's language and communicative proficiencies. ${ }^{3}$ We utilized the two versions of the CDI at baseline (wave 1), the infant-toddler version for sampled children, 12 to 23 months old, and the toddler-preschooler version, for children 24 to 42 months. The CDI is one of a few instruments for which reliability and validity studies have been completed for this age range (Fenson et al., 1994). Two CDI subscales for both age groups prove predictive of wave 2 cognitive and language proficiency: word knowledge or usage and communicative complexity. From raw scores we derive standardized performance scores for each subscale in each age group. We then combine the standardized scores across the two age cohorts and use these as controls for children's baseline levels of cognitive and language proficiency. ${ }^{4}$ All estimation models control on child age.

During the wave 2 home visits we administered the Bracken Basic Concept Scale, a measure of children's basic language and cognitive proficiency in a variety of domains (Psychological Corporation, 1998). The Bracken instrument, administered in English or Spanish, consists of six subscales that yield a "school readiness composite" and five additional subscales pertaining to self and social awareness, understanding of direction and position; understanding of texture and physical materials; understanding of quantity; and understanding of time and sequences of events. We use the Bracken scaled scores, adjusted for child age.

To further assess children's school readiness skills at wave 2, interviewers administered the story and print concepts portion of the Family and Child Experiences Survey (FACES), developed for the current national evaluation of Head Start. ${ }^{5}$ These items involve reading a simple storybook, Where's My Teddy, to the focus child, then assessing the child's familiarity with the structure and print conventions of children's books, comprehension of the story, and recognition of basic words. We also assessed school readiness skills through a series of questions within the maternal interview related to whether the child could write his or her name, how far the child was able to count, and proficiency in drawing letters and pictures rather than 
scribbling on paper. These items were drawn from National Household Education Survey (NHES; Zill, Collins, West, \& Hausken, 1995). We derived an internally reliable composite measuring "mother-assessed cognition" from these individual items.

Children's social development. In both waves, mothers completed subscales of the Child Behavior Checklist (CBCL 2/3) which assesses behavioral and emotional problems of toddlers and preschoolers (derived from Achenbach, 1992). The CBCL includes items such as "(child) cries a lot," and "(child) destroys (his/her) own things." We combined individual items to create a social problems composite and two complete subscales for aggressive and destructive behaviors (Achenbach, Edelbrookm, \& Howell, 1987). ${ }^{6}$ The CBCL has been used in large national surveys such as the National Longitudinal Study of Youth (NLSY) (Baker, Keck, Mott, \& Quinlan, 1993). It has also been shown to be predictive of outcomes in later childhood (Achenbach, Edelbrookem, \& Howell, 1987; Shaw, Winslow, Owens, \& Hood, 1998; Zaslow, McGroder, Moore, \& Le Menestrel, 1999).

Table 3 details children's cognitive proficiencies and social-developmental levels. The four-year olds participating in our study score predictably lower on the Bracken scales, compared to national norms. ${ }^{7}$ Our sample of four year-olds also showed lower proficiency on basic school readiness items, such as the ability to write one's first name or count out loud to 20 , compared to children sampled for the national Head Start evaluation. Compared to the CBCL scores of four-year olds in the NLSY, our participating mothers reported a higher incidence of behavioral problems for their four-year olds on certain items, but these differences were not as consistent as gaps in the cognitive and school readiness measures. ${ }^{8}$

[Table 3 about here]

\section{Data Analysis}

Examining possible selection effects. Since mothers in our study were not randomly assigned to different types of child care or quality conditions, selection bias is a concern. Maternal or home attributes may influence both the selection of center care and children's rate of development. For example, if more highly educated mothers choose center-based care for their children, rather than home-based care, a mean difference in child outcomes could be due to parental differences, not to causal effects of child care settings. The same selection process may apply to the quality and stability of care arrangements selected by parents, independent of type. 
We know this is likely in national probability samples (Burchinal, 1999; Singer, Fuller, Keiley, \& Wolf, 1998); but, we don't know the extent to which family demand factors or institutional allocation accounts for the type and quality of care that low-income children receive.

We employ three strategies to address potential selection bias. First, we include a number of statistical controls for mother, child, and family attributes that may be associated with both children's developmental outcomes and care selection. These include the mother's school attainment (a dummy variable indicating that the mother did not complete high school), mother's cognitive and language proficiency (PPVT score), ethnicity, mental health, work status and earnings, the parenting practices identified in the HOME Inventory, child's age, and child's earlier cognitive, language, and social-developmental outcomes (at baseline, wave 1). We also control for mother's location (San Jose and San Francisco, with Tampa as the base). Second, we explicitly model child care selection by examining whether an array of variables related to family background, mother's income, work and welfare experience, local availability of center enrollment slots, and child outcomes predict the type of care selected. We conducted a similar analysis for the level of child care quality selected by mothers. Finally, we examine the possibility of using local enrollment capacity of child care centers as an instrument for whether a child attended a center. ${ }^{9}$ Unfortunately, local availability proved to be a poor instrument: it did not predict child care use or type at the census tract level.

Estimating child care effects over time. We begin by employing ordinary least squares regression to determine the effects of child care settings on children's cognitive and social outcomes, after taking into account the control variables described above. We consider three models, each one adding additional predictors to the basic model. In the first step, we include only the controls for the child's cognitive proficiency (or social-developmental) levels at baseline (wave 1), maternal and family attributes, and site. The second step adds predictors for work-welfare group membership, income, and parenting practices. The third model adds interactions between site and center use to the basic model. These interactions capture any differential child-development effects stemming from differences in mean center quality levels among the sites. To investigate the self-selection issues, we model mother's selection into different types of child care using multinomial logit regressions.

Similar to other longitudinal field studies, we encounter missing data in our sample due to none responses to some questions. Among families participating at wave 2, we were unable to 
complete home visits, and thus complete child assessments, for 11 percent of the cases. When children were unable to perform at minimal levels on the Bracken, usually the youngest children

in the sample, field staff did not attempt the child assessment battery. ${ }^{10}$ The Bracken is thus more likely to be missing for the youngest children. There is no difference between those with missing and non-missing data on the Bracken in terms of social problems, wave 1 cognitive measures, or mother's PPVT scores. There are some missing data on the control variables, as well. So as to include as many observations as possible, we recode missing values to the mean and include a dummy indicating missing data for the following control variables: children's baseline cognitive scores, mother's PPVT scores, mother's mental health, and children's social problems in wave 1. This adjustment does not change the substance of our results.

\section{RESULTS}

\section{Positive Effects From Center Participation}

We begin by reporting on the estimated effects of participation in different types of care on children's cognitive proficiencies at wave 2, controlling for background characteristics and proficiency levels at baseline (wave 1). Table 4 details results for the Bracken scales, and Table 5 reports the corresponding models for the FACES storybook assessment and mother-reported cognitive skills related to school readiness. We observe a strong, significant, and positive effect of participation in center-based programs on almost all cognitive outcomes, relative to children who remained with individual kith or kin providers (the base). Only the Bracken subscales related to direction and time are not significantly predicted by center use.

We compute effect sizes in standard deviation units to gauge the magnitude of the effects. These estimates suggest that experience in a center at both waves increases Bracken total and school readiness composite scores by 0.6 and 0.4 standard deviations ( $\underline{\mathrm{SD}})$, respectively. In comparison to individual kith and kin providers, center participation in both waves also increases children's scores on the FACES storybook scales. The results are reported in Table 5. The effect sizes for knowledge of book mechanics, comprehension, and book familiarity subscales are $0.3,0.4$, and $0.5 \underline{\mathrm{SD}}$, respectively. Mother-assessed cognition scores were $0.3 \underline{\mathrm{SD}}$ higher for children in center care at both waves 1 and 2 than for children in kith and kin arrangements.

[Tables 4 and 5 about here] 
The large effects from center participation are evident not only for those attending centers during both data waves, but also for the subset of children that moved to a center program between wave 1 and wave 2. On the FACES subscale, children who moved to a center scored 0.4 to $0.5 \underline{\mathrm{SD}}$ higher, compared with those cared for by kith or kin at both waves. A positive relationship between cognitive development and moving to a center is evident on the Bracken measures as well, yet the magnitude is smaller compared to children participating in centers at both waves. In general, the effects of center participation are strongest for school readiness measures, such as the Bracken school readiness composite and the FACES storybook items.

The center effects remain positive and significant (except for the Bracken direction and time subscales) after controlling for mother's education, children's baseline cognitive outcomes, site effects, age of the children, and mother's cognitive proficiency (PPVT score). Mother's PPVT displays a positive and significant impact on almost all of the child's cognitive proficiencies. However, the magnitude of this impact is on average only about $0.15 \underline{\mathrm{SD}}$, approximately half as strong as the impact of center enrollment. After adjusting for mother's cognitive ability, mothers having a high school diploma does not significantly affect children's cognitive development. Children with African American or Latina mothers tend to score lower on the cognitive outcomes. Those children in San Jose and San Francisco show higher cognitive growth than those in Florida, especially on school readiness measures. This local difference may be due to the higher center quality observed in the two California sites. As expected, the wave 1 measures of children's cognitive proficiency are strongly predictive of wave 2 outcomes.

Effects of child care type on social development are less consistent. We report in Table 6 similar regressions predicting social-developmental outcomes (CBCL scales). The point estimates indicate that children participating in FCCHs exhibit more behavioral problems than those in other types of care settings; but the only statistically significant effect is that children attending FCCHs have more aggressive behaviors than children cared for by kith or kin in both waves. This relationship is large, $0.42 \underline{\mathrm{SD}}$.

[Table 6 about here]

Consistent with other studies, we find that the mother's emotional depression is associated with a higher incidence of children's social problems (Graham, 1989; Zaslow et al., 1998). Given the high proportion of mothers exhibiting depressive symptoms in our sample, the 
link between depression and social development provides evidence that mothers' poor mental health may significantly hinder the social development of many low-income children. Mother's mental health, however, does not significantly influence children's cognitive outcomes (results not shown). African-American children, those with early social problems as measured in wave 1, and those with mothers who did not complete high school also are more likely to display social problems.

\section{Including Proximal Determinants of Development}

The next set of models includes additional determinants of children's development related to mother's income, work and welfare status, and parenting practices, controlling for the effects of all previous predictors. We separate these additional factors from the earlier set because of the possibility that they are jointly determined with the choice of child care settings. All variables included in the models in Tables 4, 5, and 6 are included in these analyses as well. In Table 7 we see that the number of books in the home has a positive and significant effect on the FACES and mother-assessed school readiness measures. Children whose mothers read with them and take them to the library or museum more frequently also display fewer social problems (effect sizes of 0.14 and $0.19 \underline{\mathrm{SD}}$, respectively). Children exhibit fewer social problems when their mothers are receiving welfare income and not working for wages at wave 2 (marginally significant at $\underline{\mathrm{p}}<.10$ ). Mother's monthly income (from earnings and welfare) shows little effect on children's outcomes when all other variables are taken into account, though earnings is marginally negatively related to mother's assessment of the child. Importantly, the center effect remains strong even after the addition of these variables. The center effect for the scores on the Bracken, FACES, and mother-assessed cognition and readiness are 0.6, 0.6, and $0.2 \underline{\mathrm{SD}}$, respectively.

[Table 7 about here]

Site, Quality, and Stability Effects

The results in Table 2 suggest that the quality of center care may be higher in California counties, especially in San Jose. Because of this, we might expect the effect of centers on children's outcomes to be greater in these counties. Table 8 shows that the center effect for the Bracken school readiness composite, mother-assessed cognition and social development is 
stronger for children in San Jose, after taking into account all previous predictors. To get beneath these site differences, we next directly examine the effect of several measures of quality on child outcomes after additionally taking into account indicators of provider stability.

[Table 8 about here]

In Table 9 we report estimated effects of child care stability and quality, net the effects of all previously entered predictors. The comparison group for child care settings remains kith and kin caregivers during both waves of data collection. To simplify this display, we report on our four major composites: total Bracken score, Bracken school readiness composite, FACES storybook assessment, and the social problems index (CBCL). We see that children who had attended their current setting for more months, prior to the wave 2 interview, displayed higher cognitive proficiencies at wave 2 . In other words, stability of care has a strong and consistent positive impact on child outcomes. The Arnett caregiver interaction scale, administered in center and home settings, significantly predicts scores on the FACES composite and on the CBCL composite. Children in settings with higher Arnett scores display greater reading readiness and fewer social problems. The provider's education level is consistently and strongly related to the Bracken composites. Children in settings with more educated providers score higher on both the total Bracken index and the school readiness composite.

[Table 9 about here]

Note that exposure to a center continues to display a positive effect on the Bracken total score and the FACES composite, and exposure to a FCCH continues to display increased social problems, even after taking into account these stability and quality factors. Unfortunately, we do not have direct observational data on classroom activities or the "intended curriculum" of the centers in which children participated. That data may have enabled us to explain the positive center effect. Overall, the positive effects for cognitive and language development are consistent with earlier work with low-income populations.

\section{Selection Findings}

Results from multinomial logit models that predict type of care selected appear in Table 10. The first model includes as predictors mother's ethnicity, site, mother's educational attainment and cognitive proficiency (PPVT), along with maternal income and employment status. The second model includes additional predictors of the availability of center enrollment 
slots (within each mother's census tract) and child proficiencies at baseline (wave 1). Results from the first model show that mothers who live in San Francisco or San Jose are less likely to choose center care than those in Tampa, possibly due to higher center availability in Tampa (authors' citation). We also see some difference by background characteristics. African American mothers are more likely to choose centers and FCCHs over kith and kin providers, and Asian American mothers are more likely to choose FCCHs over individual providers. Center care is also preferred for older children. Employed mothers are more likely to choose FCCHs than kith or kin.

\section{[Table 10 about here]}

In the second model we see that the observed availability of center enrollment slots in the mother's census tract does not predict type of care selected. This rules out using the capacity measure as an instrument for center use. Mothers with high PPVT scores are more likely to select some type of nonparental child care, perhaps because they are more likely to be employed. But within the set of nonparental care choices they are no more likely to select centers. The same pattern holds for mothers without a high school diploma: they are less likely to care for their own child. We ran the same models for the quality of care selected. Mothers in San Jose were more likely to enroll their child in a higher quality setting, perhaps linked to the availability of higher quality programs in this site. No family-level factors were significantly related to the quality measures.

\section{DISCUSSION}

This study examined the effects of child care participation, quality, and stability on children's cognitive and social outcomes. We find a consistent, positive, and strong relationship between rates of child development in the cognitive domain and participation in center-based programs. These developmental effects are strongest for measures of school readiness and for children who were in a center at both wave 1 and wave 2 of our study. The center effect remains sizable even in models that include other possible determinants of development, such as age, ethnicity, mother's education, mother's work and welfare status, and income. By directly assessing the mother's cognitive proficiency (PPVT) and other proximal determinants of child development, including parenting practices, we are able to minimize the likelihood of selection bias when modeling the discrete effect of center-based care. 
In addition to exposure to center-based care, child care quality also affects children's cognitive and language development. This effect appears to stem partially from the character of social interaction between the caregiver and the child (the Arnett measure) in both center and home-based arrangements. Positive effects from the provider's education level were also evident. Future work might attempt to identify how provider education operates through mediators - such as increased sensitivity to, or more careful communication with, children - to advance youngsters' cognitive growth.

We also found that the Arnett interaction measure was predictive of fewer socialbehavior problems, and this applied to children in center and home-based arrangements. This is a promising finding, but more work is necessary to understand how these child-caregiver interactions would lead to less aggression and problematic behavior in the home, the setting in which mothers assess these behaviors. Also, children showed more social problems when in the care of providers with less than a high school education. Similarly, children attending FCCHs tended to exhibit higher levels of aggression than those staying with individual kith or kin members.

Our selection analysis lends support to a causal interpretation of the results, though we can not be sure that we have accounted for all factors that affect both the choices of care and child outcomes. The selection results in Table 10, including the lack of effect from mother's education or cognitive ability, or from the child's cognitive proficiency, suggest that the most obvious sources of bias - more able mothers choosing centers or more able children being placed in centers - are not likely to be driving the results. In addition, the stronger effect of centers on school readiness, in comparison to other measures, lends further support to the causal claim (for relative effects sizes see Table 11)

[Tables 11 about here]

Why might selection not be as important in our sample as it has been shown to be in middle income samples (Belsky, Spritz, \& Crnic, 1996; Tresch Owen \& Cox, 1988)? The weakness of maternal and family-level factors in explaining the type or quality of care selected may be linked to the rising strength of allocation processes within welfare and child care agencies. That is, as the share of families receiving subsidized child care rises (Collins et al., 2000), institutional practices may become more influential in determining which families are allocated slots in centers or child care vouchers. At the same time, states and counties vary 
widely in their funding for center-based programs and the distribution of quality across centers (Fuller, Kagan, Caspary, \& Gauthier, 2002). In these ways, family-level demand factors in this subsidized portion of the sector may be eclipsed by institutional practices.

While selection may not be biasing our results, our family sample is restricted to three counties; generalizing these results to the national population of families moving from welfare to work is difficult. The advantage of sampling families in contrasting communities is that we can illuminate how the availability and quality of child care options vary systematically across local areas. Our initial descriptive findings demonstrate that child care quality varies substantially across our three research sites, with Tampa having the lowest quality care. These organizational conditions may act to mediate the influence of new work pressures and rising levels of maternal employment on the early development of children (Fuller, Kagan, Caspary, \& Gauthier, 2002). Single mothers in Tampa and San Jose, for example, may face similar pressures to move from welfare to work. Yet when mothers in San Jose find a center slot, their children are much more likely to experience high-quality care than those in Tampa.

This study contributes to the literature on child care effects by focusing on low-income families moving from welfare to work. Earlier work on child care effects either focused on middle-class families or drew from diverse samples with only a small subset of low-income households. There are few longitudinal studies of young children from low-income families, outside of studies such as the Perry Preschool Program that focused on a particular, high-quality care setting, rather than a range of care available in poor communities. Our findings complement previous work that has found positive effects of center care and quality on children's cognitive development (Burchinal et.al, 1997; NICHD Early Child Care Research Network, 2000). It also provides new evidence on the benefits of care stability and the possible negative impact of family child care homes on children's social development. The strong positive effects stemming from center care (relative to kith and kin arrangements), as well as from quality and stability, suggest that as government invests more resources in child care, greater attention should be paid to the quality of care and ensuring center-based options for more families. 


\section{REFERENCES}

Achenbach, T. M. (1992). Manual for the Child Behavior Checklist/2-3 and 1992 Profile. Burlington, VT: University of Vermont Department of Psychiatry.

Achenbach, T.M., Edelbrookm, C., \& Howell, C. (1987). Empirically based assessment of the behavioral and emotional problems of 2-3 year old children. Journal of Abnormal and Child Psychology, 15, 629-650.

Arnett, J. (1989). Caregivers in day-care centers: Does training matter? Journal of Applied Developmental Psychology, 10, 541-552.

Baker, P., Keck, C., Mott, F., \& Quinlan, S. (1993). NLSY child handbook revised edition: A guide to the 1986-1990 NLSY child data. Columbus, OH: Center for Human Resource Research.

Barnett, W. S. (1995). Long-term effects of early childhood programs on cognitive and school outcomes. Future of Children, 5(3), 25-50.

Belsky, J., Spritz, B., \& Crnic, K. (1996). Infant attachment security and affective-cognitive information processing at age 3. Psychological Science, 7(2), 111-114.

Blau, D. M. (2001). The child care problem: An economic analysis. New York: Russell Sage Foundation.

Bradley, R. (1993). Children's home environments, health, behavior, and intervention efforts: A review using the HOME Inventory as a marker measure. Genetic, Social, and General Psychology Monographs, 119, 439-490.

Burchinal, M. R. (1999). Child care experiences and developmental outcomes. In S.Helburn (Ed.), The silent crisis in U.S. child care, Annals of the American Academy of Political and Social Science, $563,73-97$.

Burchinal, M., Campbell, F., Bryant, D. Wasik, B., \& Ramey, C. (1997). Early intervention and mediating processes in cognitive performance of children of low-income African American families. Child Development, 68, 935-954.

Campbell, F. A., \& Ramey, C. T. (1994). Effects of early intervention on intellectual and academic achievement: A follow-up study of children from low-income families. Child Development, 65(2), 684-698.

Center for Human Resource Research (2000). NLSY79: The 1998 Child and young adult data users guide. Columbus: Ohio State University.

Clarke-Stewart, A. (1999). Characteristics and quality of child care for toddlers and preschoolers. Washington DC: NICHD Early Child Care Research Network.

Clarke-Stewart, K. A., Gruber, C. P., \& Fitzgerald, L. M. (1994). Children at home and in day care. Hillsdale, NJ: Erlbaum.

Coley, R. L., Li-Grining, C., \& Chase-Lansdale, L. (in press). Low-income families' child care experiences. In H. E. Peters (Ed.), From Welfare to Child Care. New York: Russell Sage. 
Collins, A., Layzer, J., Kreader, J. L., Werner, A., \& Glantz, F. (2000). National Study of child care for low-income families: State and community substudy interim report. Cambridge, MA: Abt. Associates.

Currie, J. (2001). Early childhood education programs. Journal of Economic Perspectives, 15, 213-238.

Dunn,L. \& Dunn, L. (1997). Peabody Picture Vocabulary Test, Third Edition. Circle Pines, MN: American Guidance Service.

Fenson, L. et al. (1994). Variability in Early Communicative Development. Monographs of the Society for Research in Child Development, 59(5), 1-173.

Fuller, B., Holloway, S. D., \& Liang, X. (1996). Family selection of child-care centers: The influence of household support, ethnicity, and parental practices. Child Development, 67(6), 3320-3337.

Fuller, B., Kagan, S. L., \& Loeb, S. (2002). New Lives for Poor Families: Mothers and Young Children Move Through Welfare Reform. Technical Report.

Fuller, B., Kagan, S. L., Caspary, G., \& Gauthier, C. (2002). Welfare reform and child care options for low-income families. Future of Children, 12, 97-119.

Graham, P. (1989). Maternal depression and its impact on early child development, Early influences shaping the individual (Vol. 160, pp. 183-191). New York: Plenum Press.

Harms, T., Clifford, R., \& Cryer, D. (1997). Published ECERS and FDCRS Scales. New York: Teachers College Press.

Huston, A. C., Duncan, G. J., Granger, R., Bos, J., McLoyd, V., Mistry, R., Crosby, D., Gibson, C., Magnuson, K., Romich, J., \& Ventura, A. (2001). Work-based antipoverty programs for parents can enhance the school performance and social behavior of children. Child Development, 72(1), 318-336.

Kontos, S. J. (1991). Child care quality, family background, and children's development. Early Childhood Research Quarterly, 6(2), 249-262.

Lee, V. E., \& Loeb, S. (1995). Where do head start attendees end up? One reason why preschool effects fade out. Educational Evaluation \& Policy Analysis, 17(1), 62-82.

Love, J. M., Kisker, E., Ross, C. M., Schochet, P. Z., Brooks-Gunn, J., Paulsell, K. B., Constantine, J., Vogel, C., Fuligni, A. S., \& Brady-Smith, C. (2002). Making a Difference in the Lives of Infants and Toddlers and Their Families: The Impacts of Early Head Start. Princeton, NJ: Mathematica Policy Research, Inc.

McCarton, C. M., Brooks-Gunn, J., Wallace, I. F., \& Bauer, C. R. (1997). Results at age 8 years of early intervention for low-birth-weight premature infants: The infant health and development program. Journal of the American Medical Association, 277(2), 126-132.

McDowell, I., \& Newell, C. (1996). Measuring Health: A Guide to Rating Scales and Questionnaires. New York: Oxford University Press. 
NICHD Early Child Care Research Network. (1997). Poverty and patterns of child care. In G. J. Duncan (Ed.), Consequences of Growing Up Poor (pp. 100-131). New York: Russell Sage.

NICHD Early Child Care Research Network. (1999, April). Effects sizes from the NICHD study of early child care. Paper presented at the Society for Research in Child Development, Albuquerque.

NICHD Early Child Care Research Network. (2000). The relation of child care to cognitive and language development. Child Development, 71(4), 960-980.

Peisner-Feinberg, E. S., \& Burchinal, M. R. (1997). Relations between preschool children's child-care experiences and concurrent development: The Cost, Quality, and Outcomes Study. MerrillPalmer Quarterly, 43(3), 451-477.

Peisner-Feinberg, E. S., Burchinal, M. R., Clifford, R. M., Culkin, M. L., Howes, C., Kagan, S. L., \& Yazejian, N. (2001). The relation of preschool child-care quality to children's cognitive and social developmental trajectories through second grade. Child Development, 72(5), 1534-1553.

Phillips, D. A., Voran, M., Kisker, E., Howes, C., \& Whitebook, M. (1994). Child care for children in poverty: Opportunity or inequity? Child Development, 65(2), 472-492.

Psychological Corporation (1998). Bracken Basic Concept Scale, Revised. San Antonio: Harcourt Brace.

Reynolds, A. J., \& Temple, J. A. (1998). Extended early childhood intervention and school achievement: Age thirteen findings from the Chicago Longitudinal Study. Child Development, 69(1), 231-246.

Schweinhart, L., Barnes, H., Weikart, D., Barnett, W. S., \& Epstein, A. (1993). Significant benefits: The High/Scope Perry Preschool study through age 27 (Vol. 10). Ypsilanti, MI: High/Scope Press.

Shaw, D., Winslow, E., Owens, E., \& Hood, N. (1998). Young children's adjustment to chronic Family adversity: A longitudinal study of low-income families. Journal of the American Academy of Child and Adolescent Psychiatry, 37, 545-553.

Singer, J., Fuller, B., Keiley, M., \& Wolf, A. (1998). Early child care selection: Variation by geographic location, maternal characteristics, and family structure. Developmental Psychology, 34, 11291144.

Smith, K. (2000). Who's minding the children? Child care arrangement. Washington, DC: United States Census Bureau (Household Economic Studies, P70-70).

Tresch Owen, M., \& Cox, M. J. (1988). Maternal employment and the transition to parenthood. In A. W. Gottfried (Ed.), Maternal Employment and Children's Development: Longitudinal Research (pp. 85-119). New York: Plenum Press.

Vandell, D. L., \& Corasaniti, M. A. (1990). Variations in early child care: Do they predict subsequent social, emotional, and cognitive differences? Early Childhood Research Quarterly, 5(4), 555572.

Zaslow, M. J., McGroder, S. M., Moore, K. A., \& Le Menestrel, S. (1999, April). Behavior problems and cognitive school readiness among children in families with a history of welfare receipt: Diverging patterns and their predictors. Paper presented at the Society for Research in Child Development, Albuquerque. 
Zaslow, M. J., Moore, K. A., Brooks, J. L., Morris, P. A., Tout, K., Redd, Z. A., \& Emig, C. A. (2002). Experimental studies of welfare reform and children. Future of Children, 12(1), 79-96.

Zaslow, M. J., Oldham, E., Moore, K. A., \& Magenheim, E. (1998). Welfare families' use of early childhood care and education programs, and implications for their children's development. Early Childhood Research Quarterly, 13(4), 535-563.

Zill, N., Collins, M., West, J., \& Hausken, E. (1995). Approaching kindergarten: A look at preschools in the United States. Washington DC: National Center for Educational Statistics (No. 95-280). 
Table 1

Selected Mother and Child Characteristics

Variables

$\mathrm{N} \quad$ Mean

SD

Family Background

Child's age at Maternal Interview in months

Mother's Education and Cognitive Proficiency

Did not complete High School

Mother's PPVT score

0.44

$356 \quad 19.7$

12.3

Race/Ethnicity

Black

$451 \quad 0.41$

Hispanic

$451 \quad 0.32$

Asian

$451 \quad 0.03$

Sites

San Jose
San Francisco

Child Outcomes, Wave 1

Word Knowledge

.

Income and Employment

Worked for pay in prior year

Earned Monthly Income (\$)

On welfare during last year

On welfare and working

Not on welfare and working

Not on welfare and not working

On welfare and not working

\section{Parenting Practices}

Library/Museum

\section{Parenting Practices}

Number of books in the home

Read often

\section{Child Care Use}

Wave 1: Child care at least $10 \mathrm{hrs} /$ week

Center Care

$451 \quad 0.31$

$451 \quad 0.35$

$418 \quad 0.00$

1.00

$\begin{array}{lll}402 & 0.00 \quad 0.92\end{array}$

$\begin{array}{lll}451 & 0.83 & 0.37\end{array}$

$438 \quad 1008$

737

$448 \quad 0.82$

$451 \quad 0.22$

$451 \quad 0.31$

$451 \quad 0.16$

$451 \quad 0.31$

Family Child Care Home

Kith and Kin

Wave 2: Child care at least $10 \mathrm{hrs} /$ week

Center Care

$397 \quad 0.47$

$398 \quad 4.13$

1.04

$\begin{array}{lll}398 & 2.94 \quad 1.07\end{array}$

Family Child Care Home

Kith and Kin

$451 \quad 0.68$

$451 \quad 0.29$

$451 \quad 0.09$

$451 \quad 0.30$

$451 \quad 0.83$

$451 \quad 0.40$

$451 \quad 0.10$

$451 \quad 0.32$

Both Waves:

Center Care

Family Child Care Home

$451 \quad 0.21$

Kith and Kin

$451 \quad 0.04$

Moved to Center in Wave 2

$451 \quad 0.16$

Other

$451 \quad 0.19$

No Care

$451 \quad 0.31$

$451 \quad 0.09$ 
Table 2

Observed Child Care Quality for Centers and Home-Based Settings, by Site

\begin{tabular}{|c|c|c|c|c|}
\hline Variables & San Francisco & San Jose & Tampa & f-value \\
\hline \multicolumn{5}{|l|}{ Centers $[\underline{n}=158]$} \\
\hline Early Childhood Environment Rating Scale (ECERS) & $4.6(1.11)$ & $5.8(0.80)$ & $3.2(1.40)$ & $52.01 * * *$ \\
\hline Arnett Social Interaction Scale & $3.0(0.78)$ & $2.4(0.43)$ & $2.6(0.69)$ & $13.86^{* * *}$ \\
\hline Caregiver completed high school [\%] & $97(18)$ & $94(25)$ & $88(32)$ & \\
\hline Children in setting [group size] & $15.6(7.29)$ & $14.5(6.13)$ & $11.8(7.18)$ & $4.18^{*}$ \\
\hline Ratio of children per adult caregiver & $4.5(2.13)$ & $5.9(3.64)$ & $7.8(5.06)$ & $7.38 * * *$ \\
\hline \multicolumn{5}{|l|}{ Home-based settings $[\underline{n}=136]$} \\
\hline Family Day Care Rating Scale (FDCRS) & $2.7(1.29)$ & $2.8(1.18)$ & $3.0(1.46)$ & 0.49 \\
\hline Arnett Social Interaction Scale & $2.9(0.77)$ & $3.0(0.63)$ & $2.6(0.77)$ & 3.05 \\
\hline Caregiver completed high school [\%] & $77(43)$ & $53(50)$ & $49(51)$ & $4.31 *$ \\
\hline Children in setting [group size] & $4.3(4.27)$ & $3.5(3.06)$ & $4.1(4.83)$ & 0.69 \\
\hline Ratio of children per adult caregiver & $2.0(1.42)$ & $2.2(1.62)$ & $2.7(2.15)$ & 1.60 \\
\hline
\end{tabular}

Note: Values are means with SDs in parentheses. Average item scores reported for ECERS and Arnett measures.

$* \mathrm{p}<.05 ; * * \mathrm{p}<.01 ; * * * \mathrm{p}<.001$ 
Table 3.

Mean Scores for Children's Cognitive and Social-Developmental Outcomes

\begin{tabular}{lcccccc}
\hline Composite measure / selected items & \multicolumn{3}{c}{ Study sample } & \multicolumn{3}{c}{ National norms } \\
& N & Mean & SD & Mean & SD \\
\hline Bracken Basic Concepts Scales [age adjusted; children's mean age, 4 years] & & \\
Total scaled score & 314 & 90.4 & $(14.0)$ & 100.0 & $(15.3)$ \\
Direction \& position & 318 & 8.9 & $(5.3)$ & 10.3 & $(3.0)$ \\
Self \& social awareness & 317 & 9.0 & $(2.9)$ & 10.4 & $(3.0)$ \\
Texture \& materials & 316 & 8.5 & $(2.9)$ & 10.4 & $(3.2)$ \\
Quantity & 316 & 9.2 & $(2.9)$ & 10.5 & $(2.9)$ \\
Time \& sequence & 314 & 9.0 & $(6.5)$ & 10.3 & $(3.0)$ \\
School readiness composite & 321 & 89.7 & $(16.8)$ & 100.7 & $(15.8)$ \\
Composite national percentile score & 314 & 31 & & 50 &
\end{tabular}

FACES school readiness items [4 year-olds' scores]

Children's story book items ${ }^{\mathrm{a}}$

$\begin{array}{llll}\text { Book mechanics } & 365 & 0.5 & (0.9)\end{array}$

Familiarity with story book $\quad 366 \quad 1.3 \quad(1.1)$

Comprehension of read story $\quad 362 \quad 1.1 \quad(1.2)$

Total scores on four study items $\quad 362 \quad 2.4 \quad(2.6)$

Mother-reported cognitive, school readiness items [\%]

$\begin{array}{llll}\text { Child can count out load to } 20 & 363 & 33 & 53\end{array}$

$\begin{array}{llll}\text { Child can write first name } & 362 & 29 & 66\end{array}$

$\begin{array}{llll}\text { Can write or draw rather than scribble } & 364 & 58 & 72\end{array}$

$\begin{array}{llll}\text { Identifies primary colors by name } & 365 & 90 & 80\end{array}$

Child behavior problems [CBCL items, 4 year-olds]

$\begin{array}{llll}\text { Social problems composite }^{\mathrm{b}} & 370 & 82.6 & (14.6)\end{array}$

$\begin{array}{llll}\text { Aggressiveness subscale } & 385 & 25.8 & (6.2)\end{array}$

$\begin{array}{llll}\text { Destructive subscale } & 394 & 8.7 & (2.1)\end{array}$

Selected item comparisons [3-point scale]

$\begin{array}{llllll}\text { Destroys his/her own things } & 379 & 1.6 & (0.8) & 1.2 & (0.4)\end{array}$

$\begin{array}{llllll}\text { Is disobedient } & 382 & 1.7 & (0.6) & 1.8 & (0.5)\end{array}$

$\begin{array}{llllll}\text { Is stubborn, irritable } & 380 & 1.9 & (0.7) & 1.7 & (0.6)\end{array}$

$\begin{array}{llllll}\text { Child can't sit still, restless } & 381 & 2.0 & (0.8) & 1.8 & (0.7)\end{array}$

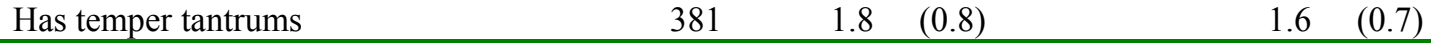

Notes: National comparative data are from Psychological Corporation (1998, Bracken manual), national Head Start evaluation (Resnick \& Tarullo, personal communication, 2002); and Achenbach (1994) and Center (2000).

${ }^{a}$ Response categories differed slightly, so comparative data not available from national Head Start evaluation. This comparison is against children from low-income families enrolled in Head Start programs.

${ }^{\mathrm{b}}$ National comparisons not available for the composites derived from the selected CBCL items administered. This comparison is against a national representative sample of 4 year-olds participating in the National Longitudinal Study of Youth. 
Table 4

Effects of Child Care Type on Cognitive Outcomes - Bracken Subscales

\begin{tabular}{|c|c|c|c|c|c|c|c|}
\hline & $\begin{array}{l}\text { Total } \\
\text { Score }\end{array}$ & Direction & $\begin{array}{l}\text { Self- } \\
\text { Esteem }\end{array}$ & Texture & Quantity & Time & $\begin{array}{c}\text { School } \\
\text { Readiness } \\
\text { Composite }\end{array}$ \\
\hline $\begin{array}{l}\text { Child Outcomes, } \\
\text { Wave } 1\end{array}$ & $(\mathrm{~N}=314)$ & $(\mathrm{N}=318)$ & $(\mathrm{N}=316)$ & $(\mathrm{N}=316)$ & $(\mathrm{N}=316)$ & $(\mathrm{N}=314)$ & $(\mathrm{N}=321)$ \\
\hline Word Knowledge & $\begin{array}{l}3.01 * * \\
(.93)\end{array}$ & $\begin{array}{l}.28 \\
(.41)\end{array}$ & $\begin{array}{l}.57 * * \\
(.20)\end{array}$ & $\begin{array}{l}.61^{* *} \\
(.20)\end{array}$ & $\begin{array}{l}.56^{* *} \\
(.21)\end{array}$ & $\begin{array}{l}.37 \\
(.50)\end{array}$ & $\begin{array}{l}3.17 * * \\
(1.11)\end{array}$ \\
\hline Complex Communic. & $\begin{array}{l}1.91^{*} \\
(.91)\end{array}$ & $\begin{array}{l}.53 \\
(.39)\end{array}$ & $\begin{array}{l}.33+ \\
(.20)\end{array}$ & $\begin{array}{l}.35+ \\
(.19)\end{array}$ & $\begin{array}{l}.25 \\
(.20)\end{array}$ & $\begin{array}{l}-.28 \\
(.49)\end{array}$ & $\begin{array}{l}2.34^{*} \\
(1.08)\end{array}$ \\
\hline \multicolumn{8}{|l|}{ Family Background } \\
\hline Child Age & $\begin{array}{l}.03 \\
(.09)\end{array}$ & $\begin{array}{l}-.04 \\
(.04)\end{array}$ & $\begin{array}{l}.01 \\
(.02)\end{array}$ & $\begin{array}{l}.00 \\
(.02)\end{array}$ & $\begin{array}{l}-6.2 \mathrm{e}-4 \\
(.02)\end{array}$ & $\begin{array}{l}-.03 \\
(.05)\end{array}$ & $\begin{array}{l}.21^{*} \\
(.10)\end{array}$ \\
\hline African American & $\begin{array}{l}-4.72 * \\
(1.95)\end{array}$ & $\begin{array}{l}-.84 \\
(.85)\end{array}$ & $\begin{array}{l}-.90^{*} \\
(.42)\end{array}$ & $\begin{array}{c}-1.36 * * * \\
(.41)\end{array}$ & $\begin{array}{l}-.55 \\
(.43)\end{array}$ & $\begin{array}{l}-2.47^{*} \\
(1.05)\end{array}$ & $\begin{array}{l}-4.84^{*} \\
(2.31)\end{array}$ \\
\hline Latina & $\begin{array}{l}-3.68+ \\
(2.04)\end{array}$ & $\begin{array}{r}-1.10 \\
(.89)\end{array}$ & $\begin{array}{l}-.70 \\
(.45)\end{array}$ & $\begin{array}{l}-.65 \\
(.44)\end{array}$ & $\begin{array}{l}-.73 \\
(.45)\end{array}$ & $\begin{array}{l}-2.25^{*} \\
(1.10)\end{array}$ & $\begin{array}{l}-4.24+ \\
(2.46)\end{array}$ \\
\hline Asian American & $\begin{array}{l}-1.38 \\
(4.50)\end{array}$ & $\begin{array}{l}-1.46 \\
(1.98)\end{array}$ & $\begin{array}{l}.42 \\
(.98)\end{array}$ & $\begin{array}{l}-.01 \\
(.96)\end{array}$ & $\begin{array}{c}-.34 \\
(1.00)\end{array}$ & $\begin{array}{l}-2.94 \\
(2.42)\end{array}$ & $\begin{array}{c}1.03 \\
(5.43)\end{array}$ \\
\hline Mother's PPVT Score & $\begin{array}{c}3.07 * * * \\
(.83)\end{array}$ & $\begin{array}{l}.15 \\
(.36)\end{array}$ & $\begin{array}{l}.52 * * \\
(.18)\end{array}$ & $\begin{array}{c}.67 * * * \\
(.18)\end{array}$ & $\begin{array}{l}.53^{* *} \\
(.18)\end{array}$ & $\begin{array}{l}-.28 \\
(.45)\end{array}$ & $\begin{array}{c}2.69 * * \\
(.99)\end{array}$ \\
\hline Did not complete H.S. & $\begin{array}{c}-.69 \\
(1.59)\end{array}$ & $\begin{array}{l}.18 \\
(.70)\end{array}$ & $\begin{array}{l}.15 \\
(.35)\end{array}$ & $\begin{array}{l}-.00 \\
(.34)\end{array}$ & $\begin{array}{l}.09 \\
(.35)\end{array}$ & $\begin{array}{l}-1.06 \\
(2.39)\end{array}$ & $\begin{array}{l}-3.48+ \\
(1.90)\end{array}$ \\
\hline \multicolumn{8}{|l|}{ Sites } \\
\hline San Jose & $\begin{array}{l}3.64+ \\
(2.02)\end{array}$ & $\begin{array}{l}.45 \\
(.88)\end{array}$ & $\begin{array}{l}.930^{*} \\
(.439)\end{array}$ & $\begin{array}{l}1.21 * * \\
(.429)\end{array}$ & $\begin{array}{c}.55 \\
(.45)\end{array}$ & $\begin{array}{c}-.694 \\
(1.09)\end{array}$ & $\begin{array}{l}5.96^{*} \\
(2.41)\end{array}$ \\
\hline San Francisco & $\begin{array}{l}3.59^{*} \\
(1.80)\end{array}$ & $\begin{array}{l}.55 \\
(.78)\end{array}$ & $\begin{array}{l}.502 \\
(.389)\end{array}$ & $\begin{array}{l}.647+ \\
(.382)\end{array}$ & $\begin{array}{l}.20 \\
(.40)\end{array}$ & $\begin{array}{l}-.13 \\
(.96)\end{array}$ & $\begin{array}{c}7.22 * * * \\
(2.15)\end{array}$ \\
\hline \multicolumn{8}{|l|}{ Child Care } \\
\hline Center both waves & $\begin{array}{c}8.10^{* * * *} \\
(2.41)\end{array}$ & $\begin{array}{c}1.52 \\
(1.05)\end{array}$ & $\begin{array}{c}2.01 * * * \\
(.521)\end{array}$ & $\begin{array}{l}1.37 * * \\
(.511)\end{array}$ & $\begin{array}{c}1.59^{* *} \\
(.53)\end{array}$ & $\begin{array}{l}.85 \\
(1.29)\end{array}$ & $\begin{array}{l}5.88^{*} \\
(2.88)\end{array}$ \\
\hline $\begin{array}{l}\text { Family child care } \\
\text { home both waves }\end{array}$ & $\begin{array}{l}7.61+ \\
(4.17)\end{array}$ & $\begin{array}{c}2.41 \\
(1.83)\end{array}$ & $\begin{array}{l}.96 \\
(.91)\end{array}$ & $\begin{array}{l}-.45 \\
(.89)\end{array}$ & $\begin{array}{l}1.37 \\
(.93)\end{array}$ & $\begin{array}{l}2.36 \\
(2.24)\end{array}$ & $\begin{array}{c}6.73 \\
(5.02)\end{array}$ \\
\hline $\begin{array}{c}\text { No care waves } \\
\text { both waves }\end{array}$ & $\begin{array}{l}2.15 \\
(3.15)\end{array}$ & $\begin{array}{l}-.44 \\
(1.36)\end{array}$ & $\begin{array}{l}.56 \\
(.69)\end{array}$ & $\begin{array}{l}.87 \\
(.67)\end{array}$ & $\begin{array}{l}1.34+ \\
(.70)\end{array}$ & $\begin{array}{c}.03 \\
(1.69)\end{array}$ & $\begin{array}{l}-3.65 \\
(3.72)\end{array}$ \\
\hline $\begin{array}{l}\text { Moved to Center } \\
\text { in wave } 2\end{array}$ & $\begin{array}{l}4.84^{*} \\
(2.36)\end{array}$ & $\begin{array}{l}1.21 \\
(1.03)\end{array}$ & $\begin{array}{l}.90+ \\
(.51)\end{array}$ & $\begin{array}{l}.35 \\
(.50)\end{array}$ & $\begin{array}{l}.26 \\
(.52)\end{array}$ & $\begin{array}{c}.51 \\
(1.27)\end{array}$ & $\begin{array}{l}5.61^{*} \\
(2.81)\end{array}$ \\
\hline Other & $\begin{array}{l}4.21+ \\
(2.28)\end{array}$ & $\begin{array}{l}1.61 \\
(.99)\end{array}$ & $\begin{array}{l}.87+ \\
(.49)\end{array}$ & $\begin{array}{l}.59 \\
(.48)\end{array}$ & $\begin{array}{l}1.21+ \\
(.50)\end{array}$ & $\begin{array}{l}1.72 \\
(1.22)\end{array}$ & $\begin{array}{l}1.06 \\
(2.70)\end{array}$ \\
\hline \multicolumn{8}{|l|}{ Missing } \\
\hline Mother's PPVT Score & $\begin{array}{l}-1.5 \\
(4.45)\end{array}$ & $\begin{array}{c}-.71 \\
(1.96)\end{array}$ & $\begin{array}{l}.28 \\
(.97)\end{array}$ & $\begin{array}{l}.67 \\
(.18)\end{array}$ & $\begin{array}{l}-1.01 \\
(.99)\end{array}$ & $\begin{array}{l}-1.06 \\
(2.39)\end{array}$ & $\begin{array}{l}2.69 \\
(.991)\end{array}$ \\
\hline Word Knowledge & $\begin{array}{l}-3.67 \\
(2.92)\end{array}$ & $\begin{array}{l}-1.06 \\
(1.28)\end{array}$ & $\begin{array}{l}-.79 \\
(.64)\end{array}$ & $\begin{array}{l}.04 \\
(.62)\end{array}$ & $\begin{array}{l}-.16 \\
(.65)\end{array}$ & $\begin{array}{l}-1.06 \\
(1.57)\end{array}$ & $\begin{array}{l}-6.12+ \\
(3.53)\end{array}$ \\
\hline Complex Communic. & $\begin{array}{l}-4.91+ \\
(2.61)\end{array}$ & $\begin{array}{c}1.00 \\
(1.15)\end{array}$ & $\begin{array}{l}-.91 \\
(.57)\end{array}$ & $\begin{array}{l}-.36 \\
(.56)\end{array}$ & $\begin{array}{l}-1.18^{*} \\
(.58)\end{array}$ & $\begin{array}{c}-.89 \\
(1.40)\end{array}$ & $\begin{array}{l}-1.01 \\
(3.15)\end{array}$ \\
\hline Adj. $R^{2}$ & .24 & .0 & .18 & .22 & .14 & .00 & .23 \\
\hline
\end{tabular}

Note: Coefficients and standard errors reported. $+\mathrm{p}<.1 ;{ }^{*} \mathrm{p}<.05 ; * * \mathrm{p}<.01 ; * * * \mathrm{p}<.001$. 
Table 5

Effects of Child Care Type on Cognitive Outcomes - FACES Assessments and Baseline Child Cognitive Proficiencies

\begin{tabular}{|c|c|c|c|c|c|}
\hline & $\begin{array}{l}\text { FACES } \\
\text { Total }\end{array}$ & $\begin{array}{l}\text { Book } \\
\text { Mechanics }\end{array}$ & $\begin{array}{l}\text { Story } \\
\text { Comprehens } \\
\text { ion. }\end{array}$ & $\begin{array}{l}\text { Book } \\
\text { Familiarity }\end{array}$ & $\begin{array}{l}\text { Mother- } \\
\text { Assessed } \\
\text { Cognition }\end{array}$ \\
\hline Child Outcomes, Wave 1 & $(\mathrm{~N}=451)$ & $(\mathrm{N}=365)$ & $(\mathrm{N}=362)$ & $(\mathrm{N}-366)$ & $(\mathrm{N}=398)$ \\
\hline Word Knowledge & $\begin{array}{l}.23+ \\
(.13)\end{array}$ & $\begin{array}{l}.09 \\
(.06)\end{array}$ & $\begin{array}{l}.11 \\
(.07)\end{array}$ & $\begin{array}{l}.12+ \\
(.07)\end{array}$ & $\begin{array}{c}.20 * * * \\
(.05)\end{array}$ \\
\hline Complex communication & $\begin{array}{l}-.41 \\
(.40)\end{array}$ & $\begin{array}{l}-.00 \\
(.06)\end{array}$ & $\begin{array}{c}.07 \\
(.07)\end{array}$ & $\begin{array}{c}.06 \\
(.07)\end{array}$ & $\begin{array}{c}.16^{* * *} \\
(.05)\end{array}$ \\
\hline \multicolumn{6}{|l|}{ Family Background } \\
\hline Child Age & $\begin{array}{c}.12 * * * \\
(.01)\end{array}$ & $\begin{array}{c}.03 * * * \\
(.01)\end{array}$ & $\begin{array}{c}.06 * * * \\
(.01)\end{array}$ & $\begin{array}{c}.05 * * * \\
(.01)\end{array}$ & $\begin{array}{c}.05 * * * \\
(.01)\end{array}$ \\
\hline African American & $\begin{array}{l}-.53+ \\
(.29)\end{array}$ & $\begin{array}{c}-.36 * * \\
(.12)\end{array}$ & $\begin{array}{l}-.25 \\
(.16)\end{array}$ & $\begin{array}{l}-.18 \\
(.14)\end{array}$ & $\begin{array}{l}-.26^{*} \\
(.11)\end{array}$ \\
\hline Latina & $\begin{array}{l}-.36 \\
(.30)\end{array}$ & $\begin{array}{c}-.39 * * \\
(.13)\end{array}$ & $\begin{array}{l}-.27+ \\
(.16)\end{array}$ & $\begin{array}{l}.00 \\
(.15)\end{array}$ & $\begin{array}{c}-.22+ \\
(.12)\end{array}$ \\
\hline Asian American & $\begin{array}{l}-.84 \\
(.61)\end{array}$ & $\begin{array}{l}-.38 \\
(.28)\end{array}$ & $\begin{array}{l}-.10 \\
(.34)\end{array}$ & $\begin{array}{c}-.47 \\
(.32)\end{array}$ & $\begin{array}{l}-.47^{*} \\
(.23)\end{array}$ \\
\hline Mother's PPVT Score & $\begin{array}{l}.39 * * \\
(.13)\end{array}$ & $\begin{array}{l}.07 \\
(.05)\end{array}$ & $\begin{array}{l}.12+ \\
(.07)\end{array}$ & $\begin{array}{l}.13^{*} \\
(.06)\end{array}$ & $\begin{array}{l}.03 \\
(.05)\end{array}$ \\
\hline Did not complete High School & $\begin{array}{l}.22 \\
(.23)\end{array}$ & $\begin{array}{l}.01 \\
(.10)\end{array}$ & $\begin{array}{l}.19 \\
(.12)\end{array}$ & $\begin{array}{l}-.15 \\
(.11)\end{array}$ & $\begin{array}{c}-.19^{*} \\
(.09)\end{array}$ \\
\hline \multicolumn{6}{|l|}{ Sites } \\
\hline San Jose & $\begin{array}{l}.56+ \\
(.30)\end{array}$ & $\begin{array}{l}.17 \\
(.12)\end{array}$ & $\begin{array}{c}.07 \\
(.16)\end{array}$ & $\begin{array}{l}.18 \\
(.15)\end{array}$ & $\begin{array}{l}.29 * * \\
(.11)\end{array}$ \\
\hline San Francisco & $\begin{array}{l}-.05 \\
(.26)\end{array}$ & $\begin{array}{l}-.18 \\
(.11)\end{array}$ & $\begin{array}{l}-.03 \\
(.14)\end{array}$ & $\begin{array}{l}-.05 \\
(.13)\end{array}$ & $\begin{array}{c}.33 * * * \\
(.10)\end{array}$ \\
\hline \multicolumn{6}{|l|}{ Child Care } \\
\hline Center both waves & $\begin{array}{l}.87 * * \\
(.35)\end{array}$ & $\begin{array}{l}.28+ \\
(.14)\end{array}$ & $\begin{array}{l}.47^{*} \\
(.19)\end{array}$ & $\begin{array}{r}.51^{* *} \\
(.17)\end{array}$ & $\begin{array}{l}.29^{*} \\
(.13)\end{array}$ \\
\hline Family child care home both waves & $\begin{array}{l}.58 \\
(.58)\end{array}$ & $\begin{array}{l}-.03 \\
(.24)\end{array}$ & $\begin{array}{l}.11 \\
(.31)\end{array}$ & $\begin{array}{l}.29 \\
(.28)\end{array}$ & $\begin{array}{l}-.01 \\
(.22)\end{array}$ \\
\hline No care waves both waves & $\begin{array}{l}.46 \\
(.43)\end{array}$ & $\begin{array}{l}.14 \\
(.19)\end{array}$ & $\begin{array}{l}.22 \\
(.24)\end{array}$ & $\begin{array}{l}.45^{*} \\
(.22)\end{array}$ & $\begin{array}{l}.02 \\
(.17)\end{array}$ \\
\hline Moved to center in wave 2 & $\begin{array}{c}1.01 * * \\
(.34)\end{array}$ & $\begin{array}{l}.32 * \\
(.15)\end{array}$ & $\begin{array}{l}.48^{*} \\
(.19)\end{array}$ & $\begin{array}{c}.62 * * * \\
(.17)\end{array}$ & $\begin{array}{l}.34 * * \\
(.13)\end{array}$ \\
\hline Other & $\begin{array}{l}.90^{* *} \\
(.31)\end{array}$ & $\begin{array}{l}.24+ \\
(.13)\end{array}$ & $\begin{array}{l}.35^{*} \\
(.17)\end{array}$ & $\begin{array}{l}.42 * * \\
(.16)\end{array}$ & $\begin{array}{l}.05 \\
(.12)\end{array}$ \\
\hline Missing & & & & & \\
\hline Word Knowledge & $\begin{array}{l}-.41 \\
(.40)\end{array}$ & $\begin{array}{l}.05 \\
(.18)\end{array}$ & $\begin{array}{l}-.24 \\
(.23)\end{array}$ & $\begin{array}{l}.07 \\
(.21)\end{array}$ & $\begin{array}{l}.059 \\
(.153)\end{array}$ \\
\hline Complex Communication & $\begin{array}{l}.06 \\
(.38)\end{array}$ & $\begin{array}{l}.26 \\
(.17)\end{array}$ & $\begin{array}{l}.11 \\
(.21)\end{array}$ & $\begin{array}{l}-.06 \\
(.19)\end{array}$ & $\begin{array}{l}-.21 \\
(.15)\end{array}$ \\
\hline Mother's PPVT Score & $\begin{array}{c}-1.73 * * * \\
(.25)\end{array}$ & $\begin{array}{c}-.09 \\
(.16)\end{array}$ & $\begin{array}{l}-.02 \\
(.20)\end{array}$ & $\begin{array}{l}.08 \\
(.18)\end{array}$ & $\begin{array}{l}-.32 * \\
(.13)\end{array}$ \\
\hline Adj. $\mathbf{R}^{2}$ & .35 & .17 & .27 & .27 & .43 \\
\hline
\end{tabular}

Note: Coefficients and standard errors reported. $+\mathrm{p}<.1 ;{ }^{*} \mathrm{p}<.05 ;{ }^{* *} \mathrm{p}<.01 ; * * * \mathrm{p}<.001$. 
Table 6

Estimates of the Effect of Child Care Type on Social Development (CBCL)

\begin{tabular}{|c|c|c|c|c|}
\hline & $\begin{array}{c}\text { Social } \\
\text { Problems }\end{array}$ & $\begin{array}{c}\text { Aggressive } \\
\text { Behavior }\end{array}$ & $\begin{array}{c}\text { Destructive } \\
\text { Behavior }\end{array}$ & $\begin{array}{c}\text { Other } \\
\text { Problems }\end{array}$ \\
\hline Child Outcomes, Wave 1 & $(\mathrm{~N}=370)$ & $(\mathrm{N}=385)$ & $(\mathrm{N}=394)$ & $(\mathrm{N}=388)$ \\
\hline Word Knowledge & $\begin{array}{l}-1.11 \\
(.808)\end{array}$ & $\begin{array}{l}-.169 \\
(.353)\end{array}$ & $\begin{array}{c}-.070 \\
(.124)\end{array}$ & $\begin{array}{l}-.325 \\
(.283)\end{array}$ \\
\hline Complex communication & $\begin{array}{l}-.631 \\
(.813)\end{array}$ & $\begin{array}{l}-.188 \\
(.358)\end{array}$ & $\begin{array}{l}-.239+ \\
(.125)\end{array}$ & $\begin{array}{l}-.091 \\
(.286)\end{array}$ \\
\hline Early Social Problems & $\begin{array}{c}.663 * * * \\
(.068)\end{array}$ & $\begin{array}{c}.261^{* * *} \\
(.030)\end{array}$ & $\begin{array}{c}.091 * * * \\
(.011)\end{array}$ & $\begin{array}{c}.189 * * * \\
(.024)\end{array}$ \\
\hline \multicolumn{5}{|l|}{ Family Background } \\
\hline Child Age & $\begin{array}{l}-.050 \\
(.115)\end{array}$ & $\begin{array}{l}-.084+ \\
(.050)\end{array}$ & $\begin{array}{l}-.002 \\
(.018)\end{array}$ & $\begin{array}{c}.002 \\
(.040)\end{array}$ \\
\hline African American & $\begin{array}{c}4.88 * * \\
(1.74)\end{array}$ & $\begin{array}{l}1.47+ \\
(.764)\end{array}$ & $\begin{array}{l}.385 \\
(.269)\end{array}$ & $\begin{array}{l}1.19+ \\
(.613)\end{array}$ \\
\hline Latina & $\begin{array}{c}1.08 \\
(1.88)\end{array}$ & $\begin{array}{l}-.202 \\
(.821)\end{array}$ & $\begin{array}{l}-.015 \\
(.290)\end{array}$ & $\begin{array}{l}.259 \\
(.667)\end{array}$ \\
\hline Asian American & $\begin{array}{c}2.34 \\
(3.84)\end{array}$ & $\begin{array}{c}.000 \\
(1.65)\end{array}$ & $\begin{array}{l}-.238 \\
(.585)\end{array}$ & $\begin{array}{c}1.57 \\
(1.38)\end{array}$ \\
\hline Mother's PPVT score & $\begin{array}{l}-.624 \\
(.767)\end{array}$ & $\begin{array}{l}-.046 \\
(.337)\end{array}$ & $\begin{array}{l}-.134 \\
(.118)\end{array}$ & $\begin{array}{l}-.209 \\
(.269)\end{array}$ \\
\hline Did not complete High School & $\begin{array}{l}2.72 * \\
(1.39)\end{array}$ & $\begin{array}{l}1.36^{*} \\
(.610)\end{array}$ & $\begin{array}{l}-.020 \\
(.215)\end{array}$ & $\begin{array}{l}.518 \\
(.491)\end{array}$ \\
\hline Mother's Mental Health & $\begin{array}{c}.347 * * * \\
(.060)\end{array}$ & $\begin{array}{c}.127 * * * \\
(.026)\end{array}$ & $\begin{array}{c}.020 * * * \\
(.009)\end{array}$ & $\begin{array}{c}.124 * * * * \\
(.021)\end{array}$ \\
\hline \multicolumn{5}{|l|}{ Sites } \\
\hline San Jose & $\begin{array}{l}-.535 \\
(1.81)\end{array}$ & $\begin{array}{l}-1.02 \\
(.795)\end{array}$ & $\begin{array}{c}.042 \\
(.280)\end{array}$ & $\begin{array}{l}-.088 \\
(.643)\end{array}$ \\
\hline San Francisco & $\begin{array}{l}-3.24^{*} \\
(1.64)\end{array}$ & $\begin{array}{l}-1.41 * \\
(.715)\end{array}$ & $\begin{array}{l}-.597^{*} \\
(.251)\end{array}$ & $\begin{array}{l}-.827 \\
(.574)\end{array}$ \\
\hline \multicolumn{5}{|l|}{ Child Care, both waves } \\
\hline Center both waves & $\begin{array}{l}1.55 \\
(2.16)\end{array}$ & $\begin{array}{c}.144 \\
(.939)\end{array}$ & $\begin{array}{l}-.177 \\
(.335)\end{array}$ & $\begin{array}{l}.167 \\
(.762)\end{array}$ \\
\hline Family child care home both waves & $\begin{array}{c}4.84 \\
(3.50)\end{array}$ & $\begin{array}{l}2.59+ \\
(1.56)\end{array}$ & $\begin{array}{l}.715 \\
(.554)\end{array}$ & $\begin{array}{l}.149 \\
(1.26)\end{array}$ \\
\hline No Care both waves & $\begin{array}{c}1.24 \\
(2.65)\end{array}$ & $\begin{array}{l}-.203 \\
(1.17)\end{array}$ & $\begin{array}{l}.136 \\
(.414)\end{array}$ & $\begin{array}{l}.517 \\
(.938)\end{array}$ \\
\hline Moved to Center in wave 2 & $\begin{array}{l}-1.00 \\
(2.13)\end{array}$ & $\begin{array}{l}-.455 \\
(.929)\end{array}$ & $\begin{array}{l}-.187 \\
(.326)\end{array}$ & $\begin{array}{l}-.413 \\
(.749)\end{array}$ \\
\hline Other & $\begin{array}{l}-2.29 \\
(1.93)\end{array}$ & $\begin{array}{l}-.964 \\
(.840)\end{array}$ & $\begin{array}{l}-.179 \\
(.300)\end{array}$ & $\begin{array}{l}-.474 \\
(.682)\end{array}$ \\
\hline Missing & & & & \\
\hline Word Knowledge & $\begin{array}{l}-.003 \\
(2.55)\end{array}$ & $\begin{array}{c}-.934 \\
(1.13)\end{array}$ & $\begin{array}{l}.193 \\
(.388)\end{array}$ & $\begin{array}{c}.758 \\
(.886)\end{array}$ \\
\hline Complex Communication & $\begin{array}{c}3.78 \\
(2.49)\end{array}$ & $\begin{array}{c}.855 \\
(1.08)\end{array}$ & $\begin{array}{l}.516 \\
(.372)\end{array}$ & $\begin{array}{l}.395 \\
(.858)\end{array}$ \\
\hline Mother's PPVT Score & $\begin{array}{l}-2.70 \\
(2.09)\end{array}$ & $\begin{array}{l}-.878 \\
(.929)\end{array}$ & $\begin{array}{l}-.315 \\
(.326)\end{array}$ & $\begin{array}{l}-1.09 \\
(.740)\end{array}$ \\
\hline Mother's Mental Health & $\begin{array}{l}8.85^{*} \\
(4.21)\end{array}$ & $\begin{array}{c}3.09 \\
(1.88)\end{array}$ & $\begin{array}{l}.761 \\
(.667)\end{array}$ & $\begin{array}{l}3.14^{*} \\
(1.51)\end{array}$ \\
\hline Early Social Problems & $\begin{array}{c}42.0 * * * \\
(4.55)\end{array}$ & $\begin{array}{c}15.4^{* * *} \\
(2.02)\end{array}$ & $\begin{array}{c}5.83 * * * \\
(.716)\end{array}$ & $\begin{array}{c}11.7 * * * \\
(1.62)\end{array}$ \\
\hline Adj. $R^{2}$ & .35 & .27 & .23 & .24 \\
\hline
\end{tabular}

Note: Coefficients and standard errors reported. $+\mathrm{p}<.1 ;{ }^{*} \mathrm{p}<.05 ;{ }^{* *} \mathrm{p}<.01 ; * * * \mathrm{p}<.001$. 
Table 7

Regression Estimates of the Effect of Parenting Practices and Income on Child Outcomes

\begin{tabular}{|c|c|c|c|c|c|}
\hline & $\begin{array}{c}\text { Total } \\
\text { Bracken } \\
\text { Score }\end{array}$ & $\begin{array}{c}\text { School } \\
\text { Readiness } \\
\text { Composite }\end{array}$ & $\begin{array}{l}\text { FACES } \\
\text { Summary }\end{array}$ & $\begin{array}{c}\text { Mother } \\
\text { Assessed }\end{array}$ & $\begin{array}{c}\text { Social } \\
\text { Problems }\end{array}$ \\
\hline & $(\mathrm{N}=314)$ & $(\mathrm{N}=321)$ & $(\mathrm{N}=451)$ & $(\mathrm{N}=398)$ & $(\mathrm{N}=370)$ \\
\hline \multicolumn{6}{|l|}{ Child Care, both waves } \\
\hline Center both waves & $\begin{array}{c}8.74 * * * \\
(2.45)\end{array}$ & $\begin{array}{l}6.17^{*} \\
(2.94)\end{array}$ & $\begin{array}{l}.94 * * \\
(.34)\end{array}$ & $\begin{array}{l}.30^{*} \\
(.13)\end{array}$ & $\begin{array}{c}2.02 \\
(2.13)\end{array}$ \\
\hline $\begin{array}{l}\text { Family Child Care Home } \\
\text { both waves }\end{array}$ & $\begin{array}{l}7.05+ \\
(4.21)\end{array}$ & $\begin{array}{l}5.72 \\
(5.1)\end{array}$ & $\begin{array}{l}.43 \\
(.57)\end{array}$ & $\begin{array}{l}-.06 \\
(.22)\end{array}$ & $\begin{array}{c}4.82 \\
(3.47)\end{array}$ \\
\hline No Care both waves & $\begin{array}{c}2.88 \\
(3.30)\end{array}$ & $\begin{array}{l}-1.87 \\
(3.95)\end{array}$ & $\begin{array}{l}.80+ \\
(.43)\end{array}$ & $\begin{array}{l}.08 \\
(.17)\end{array}$ & $\begin{array}{c}.56 \\
(2.75)\end{array}$ \\
\hline Moved to Center in wave 2 & $\begin{array}{l}4.78^{*} \\
(2.40)\end{array}$ & $\begin{array}{l}5.64 * \\
(2.87)\end{array}$ & $\begin{array}{l}.99 * * \\
(.33)\end{array}$ & $\begin{array}{l}.33 * * \\
(.13)\end{array}$ & $\begin{array}{l}-1.09 \\
(2.11)\end{array}$ \\
\hline Other & $\begin{array}{l}4.62 * \\
(2.32)\end{array}$ & $\begin{array}{c}1.24 \\
(2.75)\end{array}$ & $\begin{array}{l}.92^{* *} \\
(.30)\end{array}$ & $\begin{array}{l}.06 \\
(.12)\end{array}$ & $\begin{array}{l}-2.73 \\
(1.90)\end{array}$ \\
\hline \multicolumn{6}{|l|}{ Work/Welfare Group } \\
\hline On aid, working & $\begin{array}{c}2.21 \\
(2.84)\end{array}$ & $\begin{array}{l}.214 \\
(3.42)\end{array}$ & $\begin{array}{l}.30 \\
(.38)\end{array}$ & $\begin{array}{c}.5 .84 \mathrm{E}-3 \\
(.14)\end{array}$ & $\begin{array}{l}-1.17 \\
(2.32)\end{array}$ \\
\hline On aid, not working & $\begin{array}{l}-1.97 \\
(3.27)\end{array}$ & $\begin{array}{l}-5.15 \\
(3.95)\end{array}$ & $\begin{array}{l}-.56 \\
(.44)\end{array}$ & $\begin{array}{l}-.27 \\
(.17)\end{array}$ & $\begin{array}{l}-4.83+ \\
(2.81)\end{array}$ \\
\hline Off aid, not working & $\begin{array}{l}.330 \\
(2.42)\end{array}$ & $\begin{array}{c}-.45 \\
(2.88)\end{array}$ & $\begin{array}{l}.04 \\
(.32)\end{array}$ & $\begin{array}{r}-.22+ \\
(.13)\end{array}$ & $\begin{array}{l}2.10 \\
(2.10)\end{array}$ \\
\hline \multicolumn{6}{|l|}{ Income } \\
\hline Monthly earnings & $\begin{array}{l}-8.85 \mathrm{E}-4 \\
(1.18 \mathrm{E}-3)\end{array}$ & $\begin{array}{c}2.57 \mathrm{E}-6 \\
(1.42 \mathrm{E}-3)\end{array}$ & $\begin{array}{c}2.32 \mathrm{E}-4 \\
(1.64 \mathrm{E}-4)\end{array}$ & $\begin{array}{l}-1.1 \mathrm{E}-4+ \\
(6.36 \mathrm{E}-5)\end{array}$ & $\begin{array}{l}-5.21 \\
(3.60)\end{array}$ \\
\hline Welfare income & $\begin{array}{l}6.09 \mathrm{E}-4 \\
(5.45 \mathrm{E}-3)\end{array}$ & $\begin{array}{l}.3 .58 \mathrm{E}-3 \\
(6.60 \mathrm{E}-3)\end{array}$ & $\begin{array}{l}3.43 \mathrm{E}-4 \\
(7.12 \mathrm{E}-4)\end{array}$ & $\begin{array}{l}-2.22 \mathrm{E}-4 \\
(2.7 \mathrm{E}-4)\end{array}$ & $\begin{array}{l}(7.62 \mathrm{E}-3) \\
(4.41 \mathrm{E}-3)\end{array}$ \\
\hline \multicolumn{6}{|l|}{ Parenting Practices } \\
\hline Library & $\begin{array}{c}.271 \\
(1.51)\end{array}$ & $\begin{array}{c}-.33 \\
(1.81)\end{array}$ & $\begin{array}{c}.36 \\
(.22)\end{array}$ & $\begin{array}{l}.20^{*} \\
(.08)\end{array}$ & $\begin{array}{c}-2.96^{*} \\
(1.33)\end{array}$ \\
\hline Number of books & $\begin{array}{c}.920 \\
(.808)\end{array}$ & $\begin{array}{l}.57 \\
(.97)\end{array}$ & $\begin{array}{c}.38 * * * \\
(.11)\end{array}$ & $\begin{array}{l}.09^{*} \\
(.04)\end{array}$ & $\begin{array}{l}-.21 \\
(.67)\end{array}$ \\
\hline Read with child & $\begin{array}{l}-.314 \\
(.766)\end{array}$ & $\begin{array}{c}.44 \\
(.92)\end{array}$ & $\begin{array}{l}-.11 \\
(.11)\end{array}$ & $\begin{array}{l}.03 \\
(.04)\end{array}$ & $\begin{array}{c}-1.69 * \\
(.67)\end{array}$ \\
\hline $\operatorname{Adj.} R^{2}$ & .25 & .22 & .39 & .46 & .38 \\
\hline
\end{tabular}

Note: Regression includes all control variables in previous models. Coefficients and standard errors reported. $+\mathrm{p}<.10 ;{ }^{*} \mathrm{p}<.05 ; * * \mathrm{p}<.01 ; * * * \mathrm{p}<.001$. 
Table 8

Effects of Child Care on Children's Outcomes with Interactions between Site and Center

\begin{tabular}{lccccc}
\hline & $\begin{array}{c}\text { Total } \\
\text { Bracken }\end{array}$ & $\begin{array}{c}\text { School } \\
\text { Readines } \\
\text { Composite }\end{array}$ & $\begin{array}{c}\text { FACES } \\
\text { Summary }\end{array}$ & $\begin{array}{c}\text { Mother- } \\
\text { Assessed } \\
\text { Cognition }\end{array}$ & $\begin{array}{c}\text { Social } \\
\text { Problems }\end{array}$ \\
\hline Sites & $(\mathrm{N}=314)$ & $(\mathrm{N}=321)$ & $(\mathrm{N}=451)$ & $(\mathrm{N}=398)$ & $(\mathrm{N}=370)$ \\
San Jose & 2.86 & $4.56+$ & 0.47 & 0.12 & 1.22 \\
San Francisco & $(2.27)$ & $(2.68)$ & $(0.33)$ & $(0.12)$ & $(1.98)$ \\
& $4.01+$ & $7.81^{* *}$ & 0.040 & $0.27^{*}$ & -2.12 \\
Child Care, both waves & $(2.14)$ & $(2.54)$ & $(0.30)$ & $(0.11)$ & $(1.90)$ \\
Center both waves & & & & & \\
& $7.69^{* *}$ & 5.01 & $0.85^{*}$ & 0.04 & $4.53+$ \\
Family child care home & $(3.02)$ & $(3.60)$ & $(.44)$ & $(0.17)$ & $(2.70)$ \\
$\quad$ both waves & $8.03+$ & 7.43 & 0.63 & 0.03 & 4.68 \\
No care both waves & $(4.18)$ & $(5.02)$ & $(.58)$ & $(0.22)$ & $(3.49)$ \\
& 1.95 & -4.01 & 0.45 & -0.01 & 1.42 \\
Moved to center in wave 2 & $(3.15)$ & $(3.71)$ & $(.42)$ & $(0.16)$ & $(2.64)$ \\
& $4.68^{*}$ & 5.35 & $0.99^{* *}$ & 0.31 & -.80 \\
Other & $(2.36)$ & $(2.80)$ & $(.34)$ & $(0.13)$ & $(2.12)$ \\
& $4.00+$ & .71 & $0.88^{* *}$ & 0.01 & -1.96 \\
Site/Center Interactions & $(2.29)$ & $(2.70)$ & $(.31)$ & $(0.12)$ & $(1.93)$ \\
San Jose*Center & & & & & \\
& 5.45 & $9.76+$ & 0.82 & $1.01^{* * *}$ & $-9.27^{*}$ \\
San Francisco * Center & $(4.85)$ & $(5.81)$ & $(.69)$ & $(0.26)$ & $(4.27)$ \\
& -1.63 & -2.47 & -0.43 & 0.17 & -3.52 \\
Adj. $\mathbf{R}^{2}$ & $(3.78)$ & $(4.52)$ & $(.57)$ & $(0.21)$ & $(3.63)$ \\
\hline
\end{tabular}

Note: Regression includes all control variables from previous models. Coefficients and standard errors reported. $+\mathrm{p}<.10 ;{ }^{*} \mathrm{p}<.05 ; * * \mathrm{p}<.01 ; * * * \mathrm{p}<.001$. 
Table 9

Effects of Child Care Quality on Children's Outcomes

\begin{tabular}{|c|c|c|c|c|c|c|c|c|c|c|c|c|}
\hline & \multicolumn{3}{|c|}{ Bracken Total } & \multicolumn{3}{|c|}{ Bracken School Readiness } & \multicolumn{3}{|c|}{ FACES Total } & \multicolumn{3}{|c|}{ Social Problems } \\
\hline & $(\mathrm{N}=123)$ & $(\mathrm{N}=123)$ & $(\mathrm{N}=123)$ & $(\mathrm{N}=125)$ & $(\mathrm{N}=125)$ & $(\mathrm{N}=125)$ & $(\mathrm{N}=171)$ & $(\mathrm{N}=171)$ & $(\mathrm{N}=171)$ & $(\mathrm{N}=144)$ & $(\mathrm{N}=144)$ & $(\mathrm{N}=144)$ \\
\hline $\begin{array}{l}\text { Months in } \\
\text { Setting }\end{array}$ & $\begin{array}{l}0.17 * \\
(0.08)\end{array}$ & $\begin{array}{l}0.17 * \\
(0.08)\end{array}$ & $\begin{array}{l}0.18+ \\
(0.09)\end{array}$ & $\begin{array}{l}0.26^{*} \\
(0.11)\end{array}$ & $\begin{array}{r}0.27 * \\
(0.12)\end{array}$ & $\begin{array}{l}0.26^{*} \\
(0.13)\end{array}$ & $\begin{array}{c}0.035 * * \\
(0.013)\end{array}$ & $\begin{array}{c}0.032 * \\
(0.013)\end{array}$ & $\begin{array}{c}0.039 * * \\
(0.014)\end{array}$ & $\begin{array}{c}0.014 \\
(0.099)\end{array}$ & $\begin{array}{c}0.012 \\
(0.101)\end{array}$ & $\begin{array}{c}0.017 \\
(0.109)\end{array}$ \\
\hline $\begin{array}{l}\text { Number of } \\
\text { Settings }\end{array}$ & & $\begin{array}{c}0.098 \\
(0.096)\end{array}$ & $\begin{array}{c}0.078 \\
(0.097)\end{array}$ & & $\begin{array}{c}0.21 \\
(0.13)\end{array}$ & $\begin{array}{c}0.18 \\
(0.14)\end{array}$ & & $\begin{array}{l}-0.0001 \\
(0.015)\end{array}$ & $\begin{array}{c}-0.0021 \\
(0.015)\end{array}$ & & $\begin{array}{l}0.071 \\
(0.12)\end{array}$ & $\begin{array}{l}-0.002 \\
(0.12)\end{array}$ \\
\hline $\begin{array}{l}\text { Child Care Qual } \\
\text { Average Arnett } \\
\text { Score }\end{array}$ & $\begin{array}{c}\mathbf{y} \\
0.10 \\
(1.45)\end{array}$ & $\begin{array}{c}0.12 \\
(1.50)\end{array}$ & $\begin{array}{l}1.05 \\
(1.57)\end{array}$ & $\begin{array}{c}1.13 \\
(1.99)\end{array}$ & $\begin{array}{c}1.09 \\
(2.06)\end{array}$ & $\begin{array}{l}1.66 \\
(2.18)\end{array}$ & $\begin{array}{l}0.66 * * \\
(0.25)\end{array}$ & $\begin{array}{r}0.54^{*} \\
(0.25)\end{array}$ & $\begin{array}{c}0.52 * \\
(0.25)\end{array}$ & $\begin{array}{l}-3.05+ \\
(1.78)\end{array}$ & $\begin{array}{l}-3.35+ \\
(1.82)\end{array}$ & $\begin{array}{l}-3.65^{*} \\
(1.87)\end{array}$ \\
\hline Ratio & & $\begin{array}{c}0.48 \\
(0.39)\end{array}$ & $\begin{array}{c}0.42 \\
(0.39)\end{array}$ & & $\begin{array}{c}0.31 \\
(0.54)\end{array}$ & $\begin{array}{c}0.13 \\
(0.55)\end{array}$ & & $\begin{array}{l}0.13 * \\
(0.07)\end{array}$ & $\begin{array}{c}0.12+ \\
(0.07)\end{array}$ & & $\begin{array}{c}0.47 \\
(0.49)\end{array}$ & $\begin{array}{c}0.54 \\
(0.49)\end{array}$ \\
\hline \# in setting & & $\begin{array}{l}-0.24 \\
(0.22)\end{array}$ & $\begin{array}{c}-0.43+ \\
(0.23)\end{array}$ & & $\begin{array}{c}.005 \\
(0.30)\end{array}$ & $\begin{array}{l}0.043 \\
(0.33)\end{array}$ & & $\begin{array}{c}-0.061+ \\
(0.036)\end{array}$ & $\begin{array}{c}-0.092 * \\
(0.039)\end{array}$ & & $\begin{array}{l}-0.16 \\
(0.27)\end{array}$ & $\begin{array}{l}-0.19 \\
(0.29)\end{array}$ \\
\hline $\begin{array}{l}\text { Provider Educat } \\
<\text { High School }\end{array}$ & $\begin{array}{l}-9.55 * * \\
(3.18)\end{array}$ & & & $\begin{array}{l}-12.44 * * \\
(4.32)\end{array}$ & & & $\begin{array}{l}-0.51 \\
(0.47)\end{array}$ & & & $\begin{array}{l}-3.46 \\
(3.49)\end{array}$ & & \\
\hline High School & & $\begin{array}{l}8.29 * \\
(3.64)\end{array}$ & $\begin{array}{l}7.18^{*} \\
(3.65)\end{array}$ & & $\begin{array}{l}11.22 * \\
(4.99)\end{array}$ & $\begin{array}{l}10.62 * \\
(5.09)\end{array}$ & & $\begin{array}{c}0.32 \\
(0.54)\end{array}$ & $\begin{array}{c}0.27 \\
(0.54)\end{array}$ & & $\begin{array}{l}7.35+ \\
(4.02)\end{array}$ & $\begin{array}{l}6.89+ \\
(4.02)\end{array}$ \\
\hline Some College & & $\begin{array}{c}12.09 * * \\
(3.80)\end{array}$ & $\begin{array}{l}9.82 * * \\
(3.90)\end{array}$ & & $\begin{array}{l}11.49^{*} \\
(5.22)\end{array}$ & $\begin{array}{c}11.75^{*} \\
(5.44)\end{array}$ & & $\begin{array}{c}0.32 \\
(0.55)\end{array}$ & $\begin{array}{c}0.11 \\
(0.56)\end{array}$ & & $\begin{array}{c}0.35 \\
(4.16)\end{array}$ & $\begin{array}{c}1.62 \\
(4.30)\end{array}$ \\
\hline College + & & $\begin{array}{l}9.40 * \\
(3.90)\end{array}$ & $\begin{array}{l}6.74+ \\
(4.01)\end{array}$ & & $\begin{array}{l}10.13+ \\
(5.30)\end{array}$ & $\begin{array}{l}9.14+ \\
(5.54)\end{array}$ & & $\begin{array}{l}1.43 * \\
(0.61)\end{array}$ & $\begin{array}{l}1.29^{*} \\
(0.63)\end{array}$ & & $\begin{array}{c}2.56 \\
(4.55)\end{array}$ & $\begin{array}{c}2.99 \\
(4.66)\end{array}$ \\
\hline Other & & $\begin{array}{l}10.21 \\
(6.84)\end{array}$ & $\begin{array}{l}6.15 \\
(6.94)\end{array}$ & & $\begin{array}{l}13.07 \\
(9.46)\end{array}$ & $\begin{array}{c}9.60 \\
(9.74)\end{array}$ & & $\begin{array}{l}2.01 * \\
(0.90)\end{array}$ & $\begin{array}{l}2.08^{*} \\
(0.92)\end{array}$ & & $\begin{array}{c}3.98 \\
(6.93)\end{array}$ & $\begin{array}{c}5.80 \\
(7.11)\end{array}$ \\
\hline $\begin{array}{l}\text { Child Care, both } \\
\text { Center both wave }\end{array}$ & waves & & $\begin{array}{l}8.43 * \\
(3.85)\end{array}$ & & & $\begin{array}{c}2.09 \\
(5.45)\end{array}$ & & & $\begin{array}{l}1.23 * \\
(0.60)\end{array}$ & & & $\begin{array}{c}2.66 \\
(4.52)\end{array}$ \\
\hline $\begin{array}{c}\text { Family child care } \\
\text { both waves }\end{array}$ & ome & & $\begin{array}{c}0.18 \\
(4.60)\end{array}$ & & & $\begin{array}{l}-3.78 \\
(6.47)\end{array}$ & & & $\begin{array}{c}0.54 \\
(0.69)\end{array}$ & & & $\begin{array}{l}10.22^{*} \\
(5.15)\end{array}$ \\
\hline $\begin{array}{l}\text { Moved to center } \\
\text { in wave } 2\end{array}$ & & & $\begin{array}{l}1.86 \\
(3.93)\end{array}$ & & & $\begin{array}{c}1.38 \\
(5.56)\end{array}$ & & & $\begin{array}{c}0.65 \\
(0.62)\end{array}$ & & & $\begin{array}{c}2.42 \\
(4.76)\end{array}$ \\
\hline Other & & & $\begin{array}{c}3.80 \\
(4.27)\end{array}$ & & & $\begin{array}{l}-6.36 \\
(6.00)\end{array}$ & & & $\begin{array}{l}1.37^{*} \\
(0.63)\end{array}$ & & & $\begin{array}{l}-1.91 \\
(4.79)\end{array}$ \\
\hline Adj. $\mathbf{R}^{2}$ & 0.23 & 0.23 & 0.26 & 0.25 & 0.23 & 0.23 & 0.38 & 0.40 & 0.41 & 0.09 & 0.10 & 0.11 \\
\hline
\end{tabular}

All models include controls for wave 1 child outcomes (word knowledge and complex communication), child age, race/ethnicity (white, African-American,

Latina, Asian-American), mother's PPVT score, mother's education, and site (San Jose, San Francisco or Tampa). $+\mathrm{p}<.10 ; * \mathrm{p}<.05 ; * * \mathrm{p}<.01 ; * * * \mathrm{p}<.001$. 
Table 10

Multinomial Logit Estimates of the Relationship between Family Characteristics on Child Care Selection

\begin{tabular}{|c|c|c|c|c|c|c|c|c|c|c|}
\hline & Center & $\begin{array}{l}\text { Family } \\
\text { Child } \\
\text { Care }\end{array}$ & $\begin{array}{l}\text { No } \\
\text { Care }\end{array}$ & $\begin{array}{l}\text { Moved } \\
\text { to } \\
\text { Center }\end{array}$ & Other & Center & $\begin{array}{l}\text { Family } \\
\text { Child } \\
\text { Care }\end{array}$ & $\begin{array}{l}\text { No } \\
\text { Care }\end{array}$ & $\begin{array}{c}\text { Moved } \\
\text { To } \\
\text { Center }\end{array}$ & Other \\
\hline \multicolumn{11}{|l|}{$\overline{\text { Sites }}$} \\
\hline San Jose & $.14 * * *$ & 1.52 & 0.76 & .38 & $.28^{*}$ & $.17 * *$ & 2.50 & .22 & .45 & $.33+$ \\
\hline San Francisco & $.21 * *$ & 0.00 & 0.66 & .42 & .48 & $.20 * *$ & .00 & .36 & .50 & .38 \\
\hline \multicolumn{11}{|l|}{ Family Background } \\
\hline African American & $2.59+$ & $6.26+$ & 1.62 & 1.00 & 1.62 & 1.71 & 4.63 & 1.86 & .72 & 1.07 \\
\hline Latina & .58 & 1.03 & 0.71 & 0.58 & 1.06 & .62 & .99 & 2.48 & .57 & .89 \\
\hline Asian American & 3.45 & $6.79^{*}$ & 5.27 & 2.51 & 4.97 & 1.81 & $40.4+$ & 14.30 & 2.27 & 2.84 \\
\hline Did not complete high school & .54 & 0.76 & 0.53 & .62 & 1.25 & $.39+$ & .75 & $.28+$ & .62 & .86 \\
\hline Child's Age & $1.07 * * *$ & 1.05 & 0.99 & $1.05^{* *}$ & $1.04+$ & $1.07 * *$ & 1.05 & .98 & $1.06^{*}$ & $1.04+$ \\
\hline Mother's PPVT Score & 1.23 & 1.46 & $0.56+$ & .95 & .85 & 1.13 & 1.38 & $.44 *$ & .97 & .78 \\
\hline \multicolumn{11}{|l|}{ Income and Work } \\
\hline Working & .70 & $5.6 \mathrm{E} 7 * * *$ & 1.27 & .61 & .59 & .77 & $2.6 \mathrm{E} 7 * * *$ & .59 & .61 & .37 \\
\hline Weekly Earnings & 1.00 & 1.00 & $0.99^{* * *}$ & 1.00 & .99 & 1.00 & 1.00 & $.99^{* *}$ & 1.00 & .99 \\
\hline Months on Welfare & 1.05 & 0.97 & 1.00 & $1.11 *$ & 1.02 & 1.07 & .98 & 1.08 & $1.13 *$ & 1.05 \\
\hline Capacity & & & & & & 1.00 & 1.00 & .99 & 1.00 & 1.00 \\
\hline Word Knowledge & & & & & & 1.07 & .63 & .75 & 1.10 & .82 \\
\hline Complex Communication & & & & & & .77 & 1.74 & 1.15 & .79 & .86 \\
\hline
\end{tabular}

Note: Capacity measures availability of centers in Census tract. $\quad+\mathrm{p}<.10 ;{ }^{*} \mathrm{p}<.05 ;{ }^{* *} \mathrm{p}<.01 ; * * * \mathrm{p}<.001$. 
Table 11

Effect Sizes: Child Care Type and Quality and other Family Characteristics for Children's Cognitive and Social Outcomes

\begin{tabular}{|c|c|c|c|c|c|c|c|c|c|c|}
\hline & $\begin{array}{l}\text { Center } \\
\text { Care }\end{array}$ & $\begin{array}{l}\text { Family } \\
\text { Child } \\
\text { Care }\end{array}$ & $\begin{array}{l}\text { No } \\
\text { Care }\end{array}$ & $\begin{array}{l}\text { Moved } \\
\text { to } \\
\text { Center }\end{array}$ & $\begin{array}{l}\text { Other } \\
\text { Care }\end{array}$ & $\begin{array}{l}\text { Mom's } \\
\text { PPVT } \\
\text { Score }\end{array}$ & $\begin{array}{l}\text { Mom's } \\
\text { Mental } \\
\text { Health }\end{array}$ & $\begin{array}{l}\text { Num. } \\
\text { of } \\
\text { books }\end{array}$ & $\begin{array}{l}\text { Child } \\
\text { Care } \\
\text { Quality }\end{array}$ & $\begin{array}{l}\text { Child } \\
\text { Age }\end{array}$ \\
\hline \multicolumn{11}{|l|}{ Bracken Tests } \\
\hline Total & $.57 * * *$ & $.54+$ & .15 & $.34 *$ & $.30+$ & $.22 * * *$ & & .04 & .09 & \\
\hline School & $.35^{*}$ & .40 & -.22 & $.33^{*}$ & .06 & $.16 * *$ & & & $.21 *$ & \\
\hline \multicolumn{11}{|l|}{ Readiness } \\
\hline \multicolumn{11}{|l|}{ Composite } \\
\hline Total & $.33 * *$ & .22 & .18 & $.39 * *$ & $.34 * *$ & $.15^{* *}$ & & $.19 *$ & $.20 *$ & $.05 * * *$ \\
\hline Book Mechanics & $.32+$ & -.03 & .15 & $.36^{*}$ & $.28+$ & .08 & & & $.22 *$ & $.03 * * *$ \\
\hline $\begin{array}{l}\text { Story } \\
\text { Comprehension }\end{array}$ & $.39^{*}$ & .09 & .18 & $.40^{*}$ & $.29 *$ & $.10+$ & & & $.19+$ & $.05 * * *$ \\
\hline $\begin{array}{l}\text { Book } \\
\text { Familiarity }\end{array}$ & $.46^{* *}$ & .26 & $.40^{*}$ & $.55 * * *$ & $.47 * *$ & $.11^{*}$ & & & $.23^{*}$ & $.05 * * *$ \\
\hline $\begin{array}{l}\text { Mother- } \\
\text { Assessed }\end{array}$ & $.29 *$ & -.01 & .02 & $.37 * *$ & .05 & .03 & & $.13 *$ & .08 & $.05 * * *$ \\
\hline Cognition & & & & & & & & & & \\
\hline Social & & & & & & & & & & \\
\hline Problems & & & & & & & & & & \\
\hline Composite & .11 & .33 & .08 & -.07 & .16 & & $.02 * * *$ & & & $3.4 \mathrm{e}-3$ \\
\hline Aggressive & .02 & $.42+$ & -.03 & -.07 & .15 & & $.02 * * *$ & & & $.01 *$ \\
\hline Destructive & .08 & .34 & .06 & -.09 & -.08 & & $.01 * * *$ & & & $9.4 \mathrm{e}-4$ \\
\hline Other Problems & .03 & .03 & .11 & -.08 & -.10 & & $.03 * * *$ & & & .03 \\
\hline
\end{tabular}




\footnotetext{
${ }^{1}$ Add acknowledgment to the participating mothers, field coordinators, and funders.

${ }^{2}$ We use a cutoff of 16 for depressive symptoms.

${ }^{3}$ We also converted the CDI word usage scales into a picture version, directly administered by field staff, to help validate mother reports (authors' citation).

${ }^{4}$ The correlation between word knowledge or usage and complex communication subscales were 0.39 for the younger cohort and 0.56 for the older cohort, both significant at $\mathrm{p}<.05$ or stronger.

${ }^{5}$ Used with the permission of the Head Start Bureau, Department of Health and Human Services. Special thanks to Gary Resnick at Westat Inc. and Louisa Turillo at the Bureau for their steady cooperation. Comparative data for Head Start children appear in (authors' citation).

${ }^{6} \mathrm{~A}$ complete list of items used from the $\mathrm{CBCL}$ is available from the authors in addition to these two complete subscales.

${ }^{7}$ It is usually only appropriate to discuss differences when significance tests have been computed. Unfortunately we do not have the standard errors on the national means, so we cannot conduct these tests. However, the standard deviations, together with the sample size in our sample, indicate that the differences between our sample and the national averages are likely to be significant. In the case of the Bracken test, for example, the standard errors of the sample means for the first six measures are $2.12,0.74,0.53,0.47,0.39$, and 3.98 . The standard errors are likely to be smaller for the national means (given larger sample sizes). Even if they were the same size, the differences between the national norms and our sample would be significant at conventional levels.

${ }^{8}$ Detailed comparisons on child outcomes for participating children, relative to national samples, appear in (authors' citation).

${ }^{9}$ In an earlier paper, utilizing data from a Connecticut welfare reform experiment, we found that local availability contributed mildly and significantly to the likelihood that mothers selected center care for their young children (authors' citation).

${ }^{10}$ Sample attrition did result in a slight loss of younger children who performed at significantly lower levels on the MacArthur-CDI at wave 1. The complete sample attrition analysis appears in (authors' citation).
} 